Georgetown University Law Center

Scholarship @ GEORGETOWN LAW

2001

\title{
Two Views of the River: A Critique of the Liberal Defense of Affirmative Action
}

Charles R. Lawrence III

Georgetown University Law Center, lawrenc1@law.georgetown.edu

This paper can be downloaded free of charge from:

https://scholarship.law.georgetown.edu/facpub/340

101 Colum. L. Rev. 928-975 (2001)

This open-access article is brought to you by the Georgetown Law Library. Posted with permission of the author.

Follow this and additional works at: https://scholarship.law.georgetown.edu/facpub

Part of the Education Law Commons 


\title{
GEORGETOWN LAW Faculty Publications
}

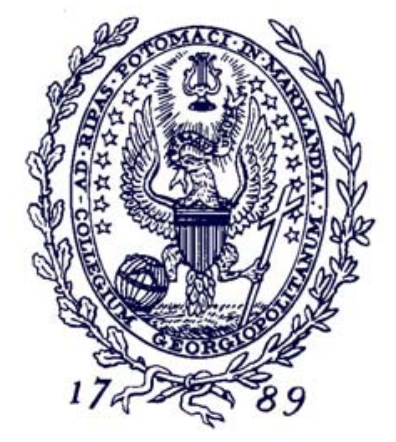

April 2010

\section{Two Views of the River: \\ A Critique of the Liberal Defense of Affirmative Action}

101 Colum. L. Rev. 928-975 (2001)

\author{
Charles R. Lawrence III \\ Professor of Law \\ Georgetown University Law Center \\ lawrenc1@law.georgetown.edu
}

This paper can be downloaded without charge from:

Scholarly Commons: http://scholarship.law.georgetown.edu/facpub/340/ 


\section{ESSAY}

\section{TWO VIEWS OF THE RIVER: A CRITIQUE OF THE LIBERAL DEFENSE OF AFFIRMATIVE ACTION}

\section{Charles $R$. Lawrence III*}

In response to the attack on affirmative action at educational institutions, the argument that the benefits of diversity necessitate keeping affirmative action has emerged as the dominant defense of race-conscious admissions policies. Describing this argument as the "liberal defense of affirmative action," Professor Laurence critiques the liberal defense because it fails to challenge the manner in which traditional standards of merit perpetuate race and class privilege, and pushes aside more radical, substantive defenses of affirmative action which articulate the need to remedy past and ongoing discrimination. While recognizing the difficulties and ambivalence inherent in advancing a new vision for defending affirmative action, Professor Lawrence points to post-Proposition 209 litigation by students of color against the Regents of the University of Califormia to articulate a theory of transformative politics upon which to base future strategies for maintaining affirmative action and dismantling racial injustice.
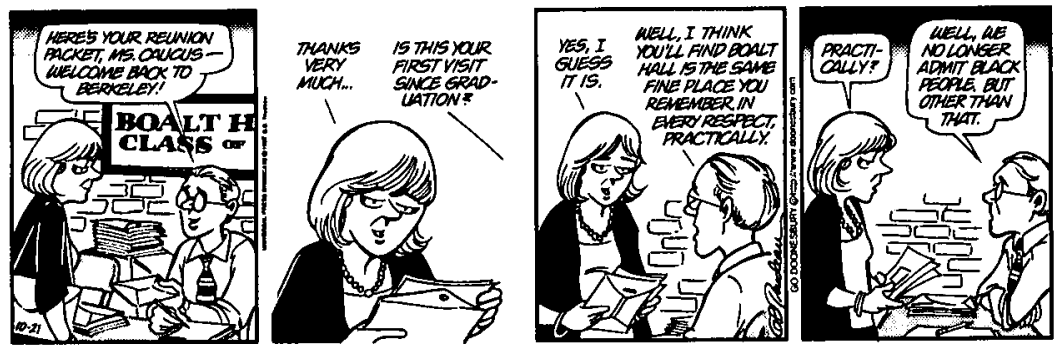

Cartoonist Gary Trudeau's genius is the truth his characters speak. The earnest young man from the law school's development office exudes liberal angst, but rather than the expected excuses and euphemisms, he simply says, "We no longer admit black people."1

Trudeau's cartoon is a commentary on a tragic moment in the history of the University of California at Berkeley School of Law, known as

* Professor of Law, Georgetown University Law Center. B.A., Haverford College, 1965; J.D., Yale Law School, 1969. My thanks go to Angela Harris, Patricia King, Mari Matsuda, Elizabeth Patterson, and Girardeau Spann for their helpful comments on previous versions of this essay, and to Anna Diamanti, Suzanne Kim, and Marsha Scipio for their excellent research assistance.

1. Garry Trudeau, Doonesbury, Oct. 21, 1997, available at http://www.doonesbury. ucomics.com/strip/dailydose/index19971021.htm (last visited Apr. 12, 2001). Doonesbury (c) 1997 G.B. Trudeau. Reprinted with permission of Universal Press Syndicate. All rights reserved. 
Boalt Hall. In the fall of 1997, only one African American matriculated in Boalt Hall's first-year class. That year, the law school had admitted only eighteen African-American applicants-fifty-nine fewer than had been admitted the year before. ${ }^{2}$ All of them decided to attend law school elsewhere, leaving as the lone black person in the entering class a young man who had deferred his admission from the previous year. ${ }^{3}$

For two and a half decades Boalt Hall had been on the front lines of the struggle for equality. ${ }^{4}$ Its student body was among the nation's most diverse. ${ }^{5}$ But more than that, Boalt Hall was a place where students were engaged. They challenged each other to learn about their different worlds and cultures. They challenged their professors to live up to the ideals they taught. They walked-out, sat-in, drafted resolutions, and held hearings and teach-ins about racism and sexism, homophobia and poverty. They organized conferences and established journals. They learned the skills of advocacy and problem solving-as often in the hallways as in the classroom-as much from their peers as from their professors. Brilliant, creative, idealistic students applied to Boalt Hall, and chose to study there, because they wanted to learn with and from their fellow students. The law school's prestige in academic and professional circles grew as it became more diverse. Affirmative action hardly diminished its stature. Rather, Boalt Hall was a great law school because of affirmative action.

Now all of that is in jeopardy. The larger tragedy is that Boalt Hall is not alone. Political and judicial attacks on affirmative action have also

2. See Jocelyn Y. Stewart, Black Colleges Woo Students Alienated by Prop. 209, L.A. Times, Nov. 25, 1997, at 1; University of California's Law Schools, at http://www.ucop. edu/acadadv/datamgmt/lawdata/lawschl2.html (last visited Apr. 12, 2001) (on file with the Columbia Law Review).

3. Ellen Nakashima \& Mike Allen, Educators Concerned About Affirmative Action, Wash. Post, Sept. 10, 1997, at B3.

4. Boalt Hall's leadership role as a significantly integrated law school did not begin until the late 1960s. From 1960 to 1964, blacks and Latinos combined made up less than one half of one percent of Boalt's entering class, and in 1964, ten years after Brown v. Board of Education, Boalt Hall bad no African-American students. Significant increases in minority enrollment did not occur until the urban uprisings of 1967 and 1968 prompted the University of California to introduce affirmative action programs that used race as an explicit "plus" factor in the admission of qualified minority applicants. Constance L. Rice, Affirmative Action in the Post-Proposition 209 Era 4-5 (Jan. 14, 1999) (paper presented at the American Council on Education's Consortium on Achieving Inclusion and Equity in Higher Education) (unpublished manuscript, on file with the Columbia Law Review)).

5. For example, within the past decade, Boalt Hall has consistently surpassed national averages for minority representation in law schools. During the 1990-1991 academic year, $13.6 \%$ of law students nationally were minorities. American Bar Association Commission on Opportunities for Minorities in the Profession, Miles to Go: Progress of Minorities in the Legal Profession 1 (1998) [hereinafter Miles to Go]. That year, 35.3\% of Boalt Hall's students were minorities. University of California, University of California at Berkeley School of Law (Boalt Hall) 2000 Annual Admissions Report 9 (2000) [bereinafter Boalt Admissions Report]. This trend continued until the 1996-1997 academic year, when $19.7 \%$ of the nation's law students were minorities, Miles to Go, supra, at 1, compared to 37.3\% of Boalt's students. Boalt Admissions Report, supra, at 9. University of California's Law Schools, supra note 2. 
devastated the law schools at UCLA ${ }^{6}$ and the University of Texas. ${ }^{7}$ The University of Michigan is fighting for its life as an integrated institution. ${ }^{8}$

The tragedy of the re-segregation of these great public law schools resonates far beyond their campuses. Consider that between 1987 and 1997, Berkeley and UCLA together trained nearly 600 black lawyers and more than 800 Latino lawyers. ${ }^{9}$ These numbers do not begin to tell the story of how those individuals have changed the complexion and culture of their state and national bars.

I write this essay as an unambivalent advocate for affirmative action. ${ }^{10}$ Affirmative action has changed my life. 1t has opened doors for me and given me the chance to do the work I love. I have watched students and colleagues walk through those same opened doors and change the institutions and communities where I work and live. I am, however,

6. See, e.g., Coalition for Econ. Equity v. Wilson, 122 F.3d 692, 701 (9th Cir. 1997) (holding that Proposition 209, a state constitutional amendment which prohibits state and local governments from adopting affirmative action programs in public employment, contracting, or education, does not violate the Fourteenth Amendment's Equal Protection Clause). For the 1996 school year, prior to the elimination of race-sensitive affirmative action at the UC graduate level, nineteen black students and forty-five Latino students were enrolled at the UCLA School of Law. In 1997, that number dropped to ten black students and thirty-nine Latino students. In 1998, the enrollment figures dropped even further, to eight black students and sixteen Latino students. In 1999, three black students and eighteen Latino students enrolled. University of California's Law Schools, supra note 2.

7. See Hopwood v. Texas, 78 F.3d 932, 948, 951 (5th Cir. 1996) (applying strict scrutiny to invalidate a state university law school's broad affirmative action program absent a showing that the program was tailored to remedy the present effects of specific instances of past discrimination). After affirmative action was eliminated at the University of Texas Law School, the number of black students accepted dropped from sixty-five in 1996 to eleven in 1997, and only four of the eleven enrolled in a first-year class of more than 400 . The number of Latino first-year students declined by $46 \%$ and the number of Native-American first-year students by $40 \%$. In the wake of Hopwood the University of Texas Law School has seen applications decline from highly-qualified white and AsianAmerican students as well as black and Latino students. Appellants' Final Brief at 8, Grutter v. Bollinger, 188 F.3d 394 (6th Cir. 1999) (No. 98-2009).

8. In a lawsuit challenging the race-conscious admissions policy at the University of Michigan's law school, the district court stated that "the attainment of a racially diverse student body is not a compelling state interest" and violated the Constitution. Grutter v. Bollinger, No. 97-CV-75928-DT (E.D. Mich. Mar. 27, 2001), 2001 U.S. Dist. LEXIS 3256, at *81, *93. For a similar case involving the University of Maryland, see Podberesky v. Kirwan, 38 F.3d 147, 152 (4th Cir. 1994) (invalidating state university scholarship program that attempted to remedy past discrimination by excluding all races from consideration except African-Americans).

9. According to combined data from the office of the registrar at each institution, Berkeley and UCLA awarded JDs to 597 black students and 801 Latino students from 1987 to 1997. This figure on Latino graduates includes Mexican-American students. Similarly, the University of Texas Law School, pre-Hopwood, had produced more than 650 AfricanAmerican and 1,300 Mexican-American lawyers. See Charles R. Lawrence 111, Race and Affirmative Action: A Critical Race Perspective, in The Politics of Law: A Progressive Critique 313, 312 (David Kairys ed., 3d ed. 1998) [hereinafter Lawrence, Race and Affirmative Actionl.

10. See Charles R. Lawrence 11 I \& Mari J. Matsuda, We Won't Go Back: Making the Case for Affirmative Action 1-2 (1997). 
less certain about where 1 stand on the subject of this essay: the liberal defense of affirmative action. Affirmative action is under siege, and I am grateful for liberal colleagues who stand beside me to defend it. Often I feel as if I am part of an army in retreat. I am distressed by that retreat, but I am also troubled by the argument that most colleges and universities now use to defend affirmative action, an argument that I refer to in this essay as the "liberal defense of affirmative action."

The liberal defense of affirmative action is often called the "diversity defense." Both the appellation and the argument have their origins in Justice Powell's opinion for the Court in Regents of the University of California v. Bakke. ${ }^{11}$ When Justice Powell found that the University of California medical school affirmative action program violated the Equal Protection Clause of the Fourteenth Amendment and Title VI of the I964 Civil Rights Act, he suggested that universities might successfully defend racesensitive admissions policies if they were necessary to achieve racially diverse student bodies. ${ }^{12}$

My chief purpose here is not to analyze Justice Powell's diversity argument. ${ }^{13}$ Rather, I am concerned that liberal supporters of affirmative action have used the diversity argument to defend affirmative action at elite universities and law schools without questioning the ways that traditional admissions criteria continue to perpetuate race and class privilege. I argue that as diversity has emerged as the dominant defense of affirmative action in the university setting, it has pushed other, more radical substantive defenses to the background. These more radical arguments focus on the need to remedy past discrimination, address present discriminatory practices, and reexamine traditional notions of merit and the role of universities in the reproduction of elites. I ask why liberal academics are so attracted to the diversity defense and suggest that the legal formalism of antidiscrimination law and the logical implications of liberal political theory influence their choice. Ultimately, I raise questions about my own attraction to and participation in the liberal defense and ask how a critical race theorist should engage his liberal allies in the midst of the day-to-day battle to keep affirmative action alive. This essay serves as an exploration of my own ambivalence about the diversity defense, even as I critique the rationale.

Part 1 sets out the "liberal defense." I use the current litigation attacking the University of Michigan's admission policies and an influential book by two former Ivy League presidents as examples of this defense. Proponents of affirmative action have made a compelling case for considering race in university admissions through the compilation of data and evidence that counter the standard anti-affirmative action arguments

11. 438 U.S. 265 (1978).

12. See id. at $312-13$.

13. Elsewhere I have criticized Justice Powell's opinion in Bakke. See Charles R. Lawrence III, Each Other's Harvest: Diversity's Deeper Meaning, 31 U.S.F. L. Rev. 757, 766-75 (1997) [hereinafter Lawrence, Harvest]. 
about the admission and supposed stigmatization of "unqualified" students of color and demonstrate the educational benefits of racial integration. Nonetheless, the purpose and effect of the diversity defense is to preserve the status quo by integrating existing elites and is, therefore, essentially conservative. Part II introduces a suit filed by black, Latino, and Filipino-American students against the University of California at Berkeley. The Berkeley example contrasts the liberal defense of affirmative action with one that places the project of racial justice at the center of the rationale for affirmative action and demonstrates how the liberal defense fails to challenge university faculties to examine their own race and class privilege.

Part III examines my own ambivalence toward the liberal defense of affirmative action. My ambivalence is both practical and ideological. If the liberal defense will garner the most support in the Supreme Court and among potential political allies because of its conservatism, how should I position myself in the debate? If I oppose the liberal defense, will I sacrifice the good that affirmative action has done in the name of principle? Will I aid and abet the attack on affirmative action from the right? If racial integration is a good, should I not join wholeheartedly in its defense? In Part IV, I suggest that affirmative action supporters can resolve this dilemma by engaging in politics that challenge the liberal defenders of affirmative action to understand and embrace their own moral commitment to ending racism. The particulars of this politics will change with context, but it must always keep before us the tension between justice and privilege.

Part V offers an alternative to the liberal defense. The alternative adopts the more radical view of equality, where the university assumes responsibility for the conditions produced by societal racism and redefines merit by asking which students will best serve the university's goal of changing conditions of inequality. It redefines racial diversity by seeking students whose experiences with and relationship to the phenomenon of racism are diverse. Ultimately, the best defense of affirmative action challenges measures of merit that replicate racial privilege and measures qualification by asking who will contribute to the dismantling of apartheid.

\section{The View from the Top: The Liberal Defense of Affirmative Action}

On October 14, 1997, a white businesswoman named Barbara Grutter filed suit in federal court against various officials of the University of Michigan and its law school. ${ }^{14}$ Her complaint alleged that the law school

14. See Grutter v. Bollinger, 16 F. Supp. 2d 797, 799 (E.D. Mich. 1998), rev'd, 188 F.3d 394 (6th Cir. 1999). On March 27, 2001, the district court judge ruled that the University of Michigan's law school violated the Constitution because it took race into consideration in admissions decisions, despite a contrary outcome in the undergraduate 
"discriminated" against her on the basis of her race because it maintained an affirmative action admissions policy that did not apply to her as a white person. Several months earlier, a similar case, Gratz v. Bollinger, was brought against the undergraduate college of the University of Michigan. ${ }^{15}$ The two suits are among the latest assaults in a nationwide legal and political attack on affirmative action that includes Proposition 209, the referendum measure that outlawed affirmative action in California, ${ }^{16}$ and Hopwood $v$. Texas, the Fifth Circuit decision that barred affirmative action at the University of Texas. ${ }^{17}$ The Center for Individual Rights (CIR), the conservative legal organization that successfully overturned affirmative action in Texas, represents both of the Michigan plaintiffs. ${ }^{18}$ The lawyers at CIR have made clear their intention to pursue the Michigan cases to the Supreme Court. They are confident that the Court will use this opportunity to overrule Justice Powell's opinion in Bakke and hold unconstitutional any use of race in university admissions. ${ }^{19}$

In Bakke, the Supreme Court's last definitive statement on affirmative action in higher education, Justice Powell reasoned that while racial classifications were always suspect and therefore subject to strict scrutiny, university faculties might use race as one factor among many in order to promote the "robust exchange of ideas" that might flow from a racially diverse academic community. ${ }^{20}$ If CIR succeeds, race-sensitive affirmative

litigation. See Jodi Wilgoren, U.S. Court Bars Race as Factor in School Entry, N.Y. Times, Mar. 28, 2001, at A1; supra note 8.

15. The district court judge decided in favor of the University of Michigan in Gratz on December 13, 2000. 122 F. Supp. 2d 811, 811 (E.D. Mich. 2000). However, the future status of the decision remains unclear. See Jodi Wilgoren, Affirmative Action Plan is Upheld at Michigan, N.Y. Times, Dec. 14, 2000, at Al6 (discussing likelihood that case will be appealed to the Supreme Court).

16. See Coalition for Econ. Equity v. Wilson, 122 F.3d 692, 696-98 (9th Cir. 1997) (describing Proposition 209).

17. 78 F.3d 932, 934 (5th Cir. 1996).

18. CIR describes itself as a "national public interest law firm" dedicated to "the uncompromising defense of individual liberties." See 1998-1999 Center for 1ndividual Rights Ann. Rep. 1 (1998-1999). A self-described conservative firm, it has litigated several precedent-setting cases challenging the constitutionality of affirmative action and has been a principal force behind several anti-affirmative-action referenda. See id.; John M. Biers, Conservative Shock Troops Take On Racial Preferences, Christian Sci. Monitor, Dec. 31, 1997 , at 3.

19. See Rene Sanchez, Final Exam for Campus Affirmative Action?: White Applicant's Test of Michigan Admissions Could Set National Policy, Wash. Post, Dec. 5, 1997, at A1.

20. Regents of the Univ. of Cal. v. Bakke, 438 U.S. 265, 313 (1978). Although Justice Powell announced the decision, the fractured Court could not produce a majority opinion and no other justice joined Justice Powell's opinion in full. Five justices signed Part V-C of Justice Powell's opinion which held that "the State has a substantial interest that legitimately may be served by a properly devised admissions program involving the competitive consideration of race and ethnic origin." 1d. at 320. 
action at public universities will cease ${ }^{21}$ and those at private universities will be in jeopardy. ${ }^{22}$

ln its answers to the Grutter and Gratz complaints, the University of Michigan stated its intention to "continue to use race as a factor in admissions, as part of a broad array of qualifications and characteristics of which racial or ethnic origin is but a single though important element."23 It is hardly surprising that the University chose to rest its defense squarely on Justice Powell's diversity rationale. For more than two decades, universities have relied on "diversity" to justify their affirmative action programs and defend them against political and legal attacks. But Michigan has fashioned its defense of diversity with unprecedented thoroughness and sophistication. Where universities such as California and Texas relied primarily on anecdotal evidence and intuitive reasoning to support their programs, Michigan has marshaled extensive data on its own students and others to demonstrate the benefits of a racially integrated community, not just to its students, but to society at large.

Michigan has argued that diversity benefits the pedagogic enterprise because students learn and grow through interaction with difference. Expert witnesses retained by the university in Gratz $v$. Bollinger have submitted a broad-ranging empirical study that concludes with a description of the wide range of benefits that flow from diversity:

Students who experienced the most racial and ethnic diversity in classroom settings and informal interactions with peers showed the greatest engagement in active thinking process, growth in intellectual engagement and motivation, and growth in intellectual and academic skills. ${ }^{24}$

The results of this study also confirm the central role of higher education in helping students become active citizens and participants in a pluralistic democracy. College students who experienced diversity

21. Although a Supreme Court decision rejecting Powell's "diversity" rationale would abolish affirmative action in its current form, it would not necessarily prevent universities from engaging in remedial affirmative action or from employing race-neutral criteria to achieve racial diversity. See infra notes $97-99$ and accompanying text.

22. See D. Frank Vinik et al., Affirmative Action in College Admissions: Practical Advice to Public and Private Institutions for Dealing with the Changing Landscape, 26 J.C. \& U.L. 395, 417-21 (2000) (reviewing the litigation and public referenda leading the attack on affirmative action and asserting that private institutions should not assume they are immune from this attack since Title VI of the Civil Rights Act could be used to challenge race-based affirmative action at private institutions).

23. Defendant's Answer at If 27, Gratz v. Bollinger, 122 F. Supp. 811 (E.D. Mich. 2000) (No. 97-CV-75231-DT); Defendant's Answer at If 28, Grutter v. Bollinger, 16 F. Supp. 2d 797 (E.D. Mich. 1998) (No. 97-CV-75928-DT).

24. Patricia Gurin, The Compelling Need for Diversity in Higher Education, at http:/ /www.umicb.edu/ urel/admissions/legal/expert/summ.html (last visited Apr. 12, 2001) (on file with the Columbia Law Review). Professor Gurin used her thirty-four years of experience in social psychological research and teaching to analyze data from a Michigan Student Study and nine years' worth of data from a national sample of institutions and students from the Cooperative Institutional Research Program. 1d. 
showed the most engagement in various forms of civic participation and the most interaction with people from different races and cultures. These effects continued after college. Experience with diversity in college had impressive effects on the extent to which graduates in the national survey lived racially and ethnically integrated lives. For the first time, a major university has amassed empirical data to show that segregated education is substandard education. A segregated university produces students with weaker cognitive skills, less capacity to work and socialize across racial lines, and a less fully developed ethic of civic obligation and participation. In other words, without racial diversity, the university could not produce the best and the brightest citizens and leaders for our democracy.

The University self-consciously modeled the shape and substance of its defense on the work of two prominent academics who have compiled and analyzed a comprehensive empirical study on affirmative action at elite colleges and universities, including the University of Michigan. William Bowen and Derek Bok, former presidents at Princeton and Harvard, published their findings in The Shape of the River: Long Term Consequences of Considering Race in College and University Admissions, ${ }^{25}$ a book that quickly became perhaps the most influential volume on the subject. ${ }^{26}$

Bowen and Bok make their bias clear from the outset. They believe that the end of affirmative action would impoverish us all. The book reminds us of the segregated world of the academy and the professions that preceded affirmative action:

1n 1965, barely 1 percent of all law students in America were black, and over one-third of them were enrolled in all-black schools. Barely 2 percent of all medical students were African American, and more than three-fourths of them attended two all-black institutions, Howard University and Meharry Medical College. ${ }^{27}$

25. William G. Bowen \& Derek Bok, The Shape of the River: Long-Term Consequences of Considering Race in College and University Admissions (1998).

26. See, e.g., Ronald Dworkin, Affirming Affirmative Action, N.Y. Rev. Books, Oct. 22, 1998, at 91 ("lt is therefore opportune that the first comprehensive and statistically sophisticated examination of the actual effects of thirty years of affirmative action in American universities has just been published."); Martha Ezzard, Tbe Real Meaning of 'Merit': A Book Georgia Policymakers Should Read, Atlanta J. \& Const., Dec. 7, 1998, at A10 ("The Bowen-Bok book should be required reading for policymakers."); Editorial, The Facts About Affirmative Action, N.Y. Times, Sept. 14, 1998, at A32 ("A new study of elite colleges provides striking confirmation of the success of affirmative action in opening opportunities and creating a whole generation of black professionals who are now leaders in their fields and their communities. No study of this magnitude has been attempted before."); David Gergen, A Study in Black and White: Why Race-Sensitive College Admissions Policies Work, U.S. News \& World Rep., Oct. 12, 1998, at 84 ("Their new book, The Shape of the River, is the most comprehensive study ever done of affirmative action in higher education, and it demands the attention of anyone who cares about American universities.").

27. Bowen \& Bok, supra note 25 , at 5 . 
The authors quote Erwin Smigel's classic study of Wall Street lawyers in the 1960s. "I only heard of three Negroes who had been hired by large law firms," reports Smigel. "Two of these were women who did not meet the client." ${ }^{28}$ This little history lesson demonstrates that affirmative action sought to bring about and, achieved in part, the desegregation of the academy and higher professions.

The Shape of the River draws on a forty-year longitudinal study of more than 80,000 black and white students who attended twenty-eight of the nation's best colleges and universities. ${ }^{29}$ It constitutes an important document and a compelling brief for race-sensitive admissions in higher education. Their findings hardly surprise many of us who have benefited from affirmative action as students and teachers. ${ }^{30}$

Bowen and Bok establish that most beneficiaries of affirmative action feel a strong sense of social responsibility and most go on to contribute to their communities in meaningful leadership roles. ${ }^{31}$ This evidence shows that affirmative action in university admissions achieves one of its primary goals: the education of individuals from under-represented and underserved minority communities who become leaders within those communities and spokespersons for the unrepresented. It answers the critics who have sought to portray the recipients of affirmative action as self-serving as well as unqualified. ${ }^{32}$

28. Id. at 4 .

29. Bowen and Bok's book analyzes a database of records, compiled by the Mellon foundation, called "College and Beyond." The twenty-eight institutions involved in the study were: Barnard College, Bryn Mawr College, Columbia College, Denison University, Duke University, Emory University, Hamilton College, Kenyon College, Miami University (Ohio), Northwestern University, Oberlin College, Pennsylvania State University, Princeton University, Rice University, Smith College, Stanford University, Swarthmore College, Wellesley College, Wesleyan University, Williams College, Tufts University, Tulane University, University of Michigan at Ann Arbor, University of North Carolina (Chapel Hill), University of Pennsylvania, Vanderbilt University, Washington University, and Yale University. The database contains information about undergraduates who matriculated in 1951, 1976, and 1989. The database records each student's race, gender, high school grades, SAT scores, college majors and grades, extracurricular activities, graduate and professional school record, and, for many, family economic and social background. It also presents information about post-university experience gathered through a detailed questionnaire. Bowen \& Bok, supra note 25, at 291-335.

30. While many black students attending these selective schools would have been rejected under a strict race-neutral regime, id. at $31-42$, the vast majority have been successful students and have excelled in their professional lives, despite facing continued discrimination in the workplace. Forty percent of the black graduates who entered the twenty-eight schools in 1976 went on to earn advanced degrees or professional degrees in law, business, or medicine, a figure slightly higher than that for their white classmates. ld. at 97 .

31. Id. at 155-73. While black and white matriculants were equally likely to participate in civic arenas, see id. at 158, "black matriculants (both women and men) were more likely than white matriculants to be leaders in more than a single civic arena." Id. at 162.

32. See Stephan Thernstrom \& Abigail Thernstrom, America in Black and White: One Nation, Indivisible 422 (1997) (arguing Martin Luther King, Jr.'s position dismissing 
Affirmative action supporters have long understood the necessity of offering a rejoinder to distorted, but increasingly accepted, images of affirmative action beneficiaries. In We Won't Go Back: Making the Case for Affirmative Action, Professor Mari Matsuda and 1 presented brief biographical portraits of several beneficiaries of affirmative action. ${ }^{33}$ We sought to remind our readers that many of their own gifted colleagues had walked through a door pushed open by affirmative action and that we would all lose were that door slammed shut again. We know from the life stories in our own circle of family, friends, colleagues, former students, and social change activists that legions of talented affirmative action beneficiaries now work in under-served communities as doctors, teachers, lawyers, and entrepreneurs. They are returning the gifts given to them by speaking out on behalf of the unheard in board rooms, classrooms, and the halls and chambers of government. The data in Bowen and Bok's study bears out our personal experience. ${ }^{34}$

Some minority critics of affirmative action like Justice Clarence Thomas, Steven Carter, Shelby Steele, and Linda Chavez have complained that affirmative action programs stigmatize and demoralize minorities. ${ }^{35}$ By contrast, overwhelming numbers of the students in Bowen

affirmative action programs as a poor substitute for "hard work"); cf. Shelby Steele, The Content of Our Character: A New Vision of Race in America 118-19 (1990) (suggesting that affirmative action encourages a "victim-focused mentality" among blacks).

33. Lawrence \& Matsuda, supra note 10, passim.

34. See Bowen \& Bok, supra note 25, at 167; see also Steven N. Keith et al., Assessing the Outcome of Affirmative Action in Medical Schools: A Study of the Class of 1975, at 22-23, 29, 34, 41-42 (1987) (finding that (1) minority medical school graduates work in primary care rather than specialty practices to a greater extent than their non-minority counterparts; (2) minority graduates practice in physician-shortage areas at twice the rate of non-minority graduates; (3) minority graduates care for significantly greater proportions of ethnic minority patients and patients supported by Medicaid; (4) a smaller portion of minority graduates enter academic medicine; (5) and only about one-half of minority graduates obtain board certification in their specialty, compared to four-fifths of non-minority graduates). The data from the Keith study may also reflect the pernicious effects of racism, rather than minority graduates' personal choices.

Professor Troy Duster has observed that these studies show that the substitution of class-based affirmative action for race-based affirmative action will not serve the purpose of bringing needed medical services to these communities. He argues that poor and working class white medical school admittees are able to change their class status by virtue of their medical degree. This ability to assimilate quickly as upper-class whites allows them to choose high-income medical specialties and practice in hospitals and communities that do little to serve poor and minority communities. Ironically, the data cited in these studies represents not just minority commitment to under-served minority neighborhoods but continuing discrimination against minorities in white neighborhoods and institutions. Black doctors serve black patients in part because it is difficult for them to get white patients. Videotape: Remarks of Troy Duster, UC Berkeley Conference, Strategies for Empowerment: Preserving Diversity in a Post-Affirmative Action World, Panel 1I: Strength Through Cooperation: Interdisciplinary and Outreach Initiatives (Apr. 16, 1999) (on file with the Columbia Law Review).

35. See, e.g., Adarand Constructors, 1nc. v. Pena, 515 U.S. 200, 240-41 (1995) (Thomas, J., concurring) ("These programs stamp minorities with a badge of inferiority."); 
and Bok's study support race-sensitive policies and think that universities should place more, not less, emphasis on racial diversity. ${ }^{36}$ They report that affirmative action not only raised their income and job status, but enhanced their self-confidence and aspirations with the knowledge that they could compete with America's best and brightest. ${ }^{37}$ Furthermore, the status they gained by their association with elite academic institutions helped to ameliorate the burden of stigma that has its origins in America's racism. ${ }^{38}$

Has the desegregation of the academy taught blacks and whites to get along better, or has affirmative action only resulted in self-segregation and greater racial tension? Again, the data supports what those of us who have lived on these campuses have seen with our own eyes. The vast majority of black and white students have made good friends across racial lines. ${ }^{39}$ For most of these students, their first interracial friendships occurred in college. Many of their parents had rarely crossed racial divides. Affirmative action holds the potential to bridge the deep racial chasm in a still-segregated nation.

Stephen L. Carter, Reflections of an Affirmative Action Baby 50 (1991) ("[T]he durable and demeaning stereotype of black people as unable to compete with white ones is reinforced by advocates of certain forms of affirmative action."); Steele, supra note 32, at 116 ("[O]ne of the most troubling effects of racial preferences for blacks is a kind of demoralization, or put another way, an enlargement of self-doubt."); Linda Chavez, Who Needs the Stigma of Affirmative Action?, Chi. Trib., Feb. 3, 1999, at 15 ("Proponents of affirmative action don't want to talk about the stigma of affirmative action and some even deny it exists. But its effects can be every bit as pernicious as old-fashioned racial prejudice.").

36. Bowen \& Bok, supra note 25, at 245-48. "While both whites and blacks are in favor of increasing the emphasis on diversity, the black matriculants assign this objective a far greater importance than their white classmates." Id. at 247. In addition, "blacks are just as likely as whites to attend the inost demanding, competitive professional schools .... They are just as appreciative of their college experience, and they tend to believe that they gained more from their undergraduate experience than do their white classmates." Id. at 261.

37. Often minorities who have attended the nation's most prestigious institutions report that they are surprised to discover that while some of their white classmates and teachers are exceptionally bright or gifted, many others are not remarkable. One of my students, a young black man who had grown up in Mississippi, said that he had attended segregated schools throughout elementary school and high school and been the smartest student in his classes. However, he always believed that the white students in the other part of town were smarter. He told me that it was not until his first year at Ohio State University, his first experience on an integrated campus, that he discovered that he was smarter than most people of all races.

38. For a discussion of the argument that affirmative action stigmatizes people of color, see Lawrence \& Matsuda, supra note 10, at 126-29.

39. Eighty-eight percent of blacks report having known well two or more white students, while $56 \%$ of their white classmates say they knew at least two blacks well. Bowen \& Bok, supra note 25, at 231. A 1994 study of more than 6,000 college students reported that minority students more frequently socialized with students of other races than did white students. Alice Dembner, Campus Racial Lines May Be Blurring: Study Counters Notion that Minorities Segregate Selves, Boston Globe, Apr. 5, 1994, at 1. 
None of these observations and arguments supporting race-sensitive affirmative action in the academy is new, but Bowen and Bok's book gave them new weight and legitimacy in the legal and political discourse. Even before the book's release, the press widely reported and discussed its findings. The authors' status as former presidents of elite lvy League schools gave visibility and prestige to the project. One reviewer suggested that Bowen and Bok wrote the book "with an eye toward [influencing] today's Supreme Court." 40 After all, in Bakke, Justice Powell singled out Harvard's minority admissions program as a model for constitutionally permissible race-based admissions. ${ }^{41}$ Indeed, judicial deference to the academic freedom of university faculties is central to his reasoning in that case. ${ }^{42}$

Moreover, the appeal to science is a powerful tool in the political and legal discourse about race, ${ }^{43}$ and Bowen and Bok situate themselves as objective empiricists. ${ }^{44}$ The Shape of the River is chock-full of statistics, graphs, tables, and multivariate regressions. The perceived roles of ideology and interest politics as driving forces in the affirmative action debate have amplified the authority of empirical evidence. The University of

40. Gergen, supra note 26 , at 84 .

41. Regents of the Univ. of Cal. v. Bakke, 438 U.S. 265, 316-19 (1978).

42. Justice Powell opined in Bakke that:

The fourth goal asserted by petitioner is the attainment of a diverse student body. This clearly is a constitutionally permissible goal for an institution of higher education. Academic freedom, though not a specifically enumerated constitutional right, long has been viewed as a special concern of the First Amendment. The freedom of a university to make its own judgments as to education includes the selection of its student body. . . " $1 \mathrm{t}$ is the business of a university to provide that atmosphere which is most conducive to speculation, experiment, and creation. 1t is an atmosphere in which there prevail "the four essential freedoms" of a university - to determine for itself on academic grounds who may teach, what may be taught, how it shall be taugbt, and who may be admitted to study."

Id. at 311-12 (quoting Sweezy v. New Hampshire, 354 U.S. 234, 263 (1957)).

43. Racists and anti-racists alike have appealed to science in our ancient and ongoing debate on the question of race and equality. See, e.g., Stephen Jay Gould, The Mismeasure of Man 20-29 (1981) (presenting a historical study of scientific racism from craniology to hereditary IQ theory); Richard J. Herrnstein \& Charles Murray, The Bell Curve: Intelligence and Class Structure in American Life 269-388 (1994) (discussing differing cognitive ability among ethnic groups in the United States). One of the most famous examples of the reliance of law and policymaking on social science was the Supreme Court's use of a study on the impact of segregation on black children's self esteem in Brown v. Board of Education. 347 U.S. 483, 494 n.11 (1954) (citing several social science studies, including Kenneth B. Clark, Effect of Prejudice and Discrimination on Personality Development (1950) (paper delivered at Mid-Century White House Conference on Cbildren and Youth)).

44. The largely positive critical response to Shape of the River revealed the success of this strategy. One reviewer began a description of the book's content as follows: "Having grown weary of debate devoid of empirical evidence, [Bowen and Bok] conducted a study to determine the truth about race-sensitive practices in the university setting." E.R. Shipp, Perspective: The Shape of the River, Denv. Post, Oct. 11, 1998, at H3. 
Michigan has recognized the benefit in likewise positioning itself. Of course, the statistical evidence has more than rhetorical power. It substantiates the most powerful claims made in favor of affirmative actionclaims that until this time relied primarily on the lived experiences of those of us who have benefited directly and indirectly from these programs. The data also refute a number of widely believed myths about affirmative action. These myths-that affirmative action has lowered educational standards, hurt minorities more than it has helped them, and exacerbated rather than relieved racial tension-remain central to the arguments made by opponents of affirmative action. As Ronald Dworkin noted in his review of The Shape of the River, those critics must now "either acknowledge [the authors'] findings or challenge them, and any challenge must match the standards of breadth and statistical professionalism that [Bowen and Bok] have achieved." 45

Nevertheless, I remain troubled by another reason for The Shape of the River's warm reception among liberals and its emergence as the model for persuading the Supreme Court to affirm the constitutionality of affirmative action. While Bowen and Bok occupy the role of "liberals" in the affirmative action debate, their defense preserves the status quo. ${ }^{46} \mathrm{It}$ leaves no room for deeper criticisms of the racial hierarchy-a hierarchy that produces unequal secondary education as well as past and ongoing racism, both deliberate and unconscious, at institutions of higher learning. I do not mean to suggest that Bowen and Bok are conservatives. I count them among my liberal allies. However, the "diversity defense" of affirmative action is, in effect, conservative. Bowen and Bok believe in racial integration as a moral and pragmatic good, but they defend the integration of an existing elite without questioning that elite's participation in the reproduction of institutional racism.

The empirical study, which forms the basis of both The Shape of the River and the University of Michigan's defense, carefully and powerfully documents the benefits of diversity. But one must remember that these studies look only to the nation's most selective colleges and universities. The studies and resulting conclusions assume that our best schools should seek first and foremost to educate a select group of influential scholars, professionals, and world leaders. They imply that not only should the mission of these institutions remain unchanged, but the

45. Dworkin, supra note 26 , at 91-92.

46. See, e.g., Terrance Sandalow, Minority Preferences Reconsidered, 97 Mich. L. Rev. 1874, 1876 (1999) (describing Bowen and Bok's focus on defending existing racesensitive admissions practices); Stephen Thernstrom \& Abigail Thernstrom, Reflections on The Shape of the River, 46 UCL.A L. Rev. 1583, 1586 (1999) (book review) ("With preferences on trial, Bowen and Bok have written a brief on ... behalf [of affirmative action supporters] designed not only to establish the facts, but to lift the flagging spirits of preference advocates in the post-Hopwood, post-Proposition 209 era as well."); Gergen, supra note 26, at 84 (“Now, with an eye toward today's Supreme Court, [Bowen and Bok] have amassed reams of new social data to support the continued use of race-sensitive polices in college admissions."). 
means for determining admission to this elite need not change significantly. The most selective colleges and universities continue to rely heavily on SAT scores in their admissions. ${ }^{47}$ Bowen and Bok use the fact that schools have not lowered their standards to admit minority students as an argument to support continuing affirmative action. 48 The chief proof that standards remain high is affirmative action admittees' success as students and in the most well-paid and high-status occupations. ${ }^{49}$

The case for diversity is a case for the integration of a privileged class. Because the liberal defense of affirmative action accepts the reproduction of elites as the primary purpose of selective colleges and universities, it neither questions the validity of standard admissions criteria used at these institutions, nor examines the ways that these criteria reinforce the effects of societal segregation and racism.

It should not surprise us that well-meaning individuals who self-identify as liberal should be attracted to an argument for racial integration that least threatens their own privilege. ${ }^{50}$ However, the liberal position on affirmative action is more than a defense mechanism adopted by academic integrationists. Liberal theory itself guides the rationale. Liberalism's focus on fair process and bad actors and its agnosticism toward continuing conditions of subordination allow the liberal defender of affirmative action to champion racial justice without confronting the moral question of whether he can define as "just" a society still significantly sep-

47. See Susan Sturm \& Lani Guinier, The Future of Affirmative Action: Reclaiming the Innovative Ideal, 84 Calif. L. Rev. 953, 957 (1996) (criticizing the continued reliance on standardized tests); Nicholas Lemann, The Great Sorting, Atlantic Monthly, Sept. 1995, at 84, 99-100 (arguing that use of the SAT achieves mixed results, sometimes at the expense of students at the bottom of the social structure who are least prepared for the test).

48. The data show that while blacks as a group scored lower than whites as a group on standardized tests, the difference in these scores did not mean that blacks were unqualified for the education they received. Bowen and Bok say that the difference in scores between black and white applicants to these schools is better explained by the fact that white applicants are spectacularly well qualified than by the assumption that black applicants were not qualified. More than $75 \%$ of the black applicants in the study had higher math SAT scores, and more than $73 \%$ had higher verbal SAT scores, than the national average of white test-takers. Bowen \& Bok, supra note 25, at 18-19. The average SAT scores of black entrants to the most selective schools in 1989 was higher than the average of all matriculants at the same institutions in 1951. 1d. at 30 . In addition, the authors challenge the notion that black students would fare better at schools with students who received comparable SAT scores: "Black students . . . with modest SAT scores graduated in larger numbers from the most selective schools than did those who attended schools in which their classmates were more like them in terms of SAT scores." Id. at 143.

49. Id. at 128.

50. See Charles R. Lawrence III, "Justice" or "Just Us": Racism and the Role of Ideology, 35 Stan. L. Rev. 831, 842 (1983) (reviewing David L. Kirp, Just Schools: The Idea of Racial Equality in American Education (1982)) (discussing the use of ideology as a defense mechanism against anxiety felt by those who hold power through means and with motives they cannot comfortably acknowledge). 
arate and unequal. ${ }^{51}$ A lawsuit filed against Berkeley makes apparent the tension in the liberal defense.

\section{I. The View From The Bottom: A Challenge To "Color Blind Meritocracy"}

On February 2, 1999, Jesus Rios, Gregory McConnell, Justine Certeza, and five other named individuals filed a class action suit against the University of California Regents and the University of California (UC) at Berkeley. Jesus Rios, a Latino, is the son of farm workers. For as long as he can remember, Jesus worked beside his parents picking apples and apricots and digging ditches from sunup to sundown. Despite the travails of migrant life, Jesus graduated from high school in the top four percent of his class. ${ }^{52}$ But when Jesus applied to Berkeley, he was told, "You don't belong here."

Gregory McConnell, an African American, is a Presidential Scholar. In high school he played soccer and varsity tennis, participated in numerous community service activities, and was a Junior Statesman of America. ${ }^{53}$ When Gregory applied to Berkeley he was told, "You don't belong here."

Justine Certeza, a Filipina American, will be the first in her family to graduate from college. In high school, she was sophomore senator, junior class secretary and senior class president. During her junior year she participated on her high school's Academic Decathlon team, which placed second in Salano County. ${ }^{54}$ She was also an "A" student. When Justine applied to Berkeley she was told, "You don't belong here."

In the year that Berkeley turned down Jesus, Gregory, and Justine, over 750 other black, Latino and Filipino-American students with similarly superior academic records were denied admission. ${ }^{55}$ Berkeley is the

51. See infra notes $65-87$ and accompanying text; see also Charles R. Lawrence III, Race, Multiculturalism, and the Jurisprudence of Transformation, 47 Stan. L. Rev. 819, 822-28 (1995) [hereinafter Lawrence, Multiculturalism] (arguing that liberal individualist theory fails the cause of anti-racism and transformative humanization because it offers a nonsubstantive approach to racism that focuses exclusively on individual harms and procedural fairness rather than the disestablishment of ideologies, systems, and conditions of racial subordination).

52. Compl. for DecI. and 1nj. Relief at 4, Rios v. Regents of the Univ. of Cal., (N.D. Cal. Feb. 2, 1999) (No. C.99-0525) [hereinafter Rios Complaint].

53. Id.

54. Id. at 6.

55. Press Release, Minority Students Sue U.C. Berkeley for Discrimination: Admissions Process Violates Federal Civil Rights Laws 2 (Feb. 2, 1999) (on file with the Columbia Law Review) [hereinafter Minority Students Sue]. Even comparing only applicants with grade point averages of 4.0 or higher, African-American, Latino, and Filipino-American students were denied admission at far higher rates than white students. Berkeley admitted $48.2 \%$ of white applicants with GPAs of 4.0 or higher, but only $31.6 \%$ of Filipino-American, 38.5\% of African-American, and 39.7\% of Latino applicants with such GPAs. 1d.; First Amended Compl. for Decl. and 1nj. Relief at 2, Rios v. Regents of the Univ. of Cal. (N.D. Cal. 1999) (No. C99-0525). The plaintiffs in the Rios litigation included 
UC system's most selective school, and of the 25,796 applicants for the 1999 freshman class, 9,858 had GPAs of 4.0.56 But a white applicant with a straight "A" average has a much better shot at getting into Berkeley than a black, Latino or Filipino applicant with the same grades. ${ }^{57}$

How could this be? How could a university committed to diversity exclude so many of the state's brightest and most talented minority students? The complaint in Rios reveals a troubling, if unsurprising, answer. The so-called "color blind" post-affirmative action admissions process at Berkeley has resurrected the old preferences for the sons and daughters of the privileged. Let me be more precise: With the end of affirmative action, it is more apparent than ever that the old-time preferences for folks who are privileged by race and class have never died. The current Berkeley admissions process creates a preference for white folks in two very concrete ways: First, it gives bonus points to high school students who are enrolled in advanced placement courses, ${ }^{58}$ and second, it relies

Filipino-American applicants but not members of other Asian-American groups, who were admitted to Berkeley at rates comparable to their white counterparts. There is a complex ambiguity in the position of Asian Americans with regard to affirmative action. Although Asian Americans have shared with other racial minorities a history of exclusion, discrimination, and violence inflicted by racism, they are rarely included among the minority groups targeted by university affirmative action programs. The high test scores of many Asian Americans often mask the continued exclusion of subgroups within the AsianAmerican community, and Asian Americans have experienced a backlash fueled by the public perception that some universities are admitting "too many Asians." The rhetoric of anti-affirmative action has employed the image of the Asian-American "model minority" to argue against the inclusion of Asian Americans in affirmative action programs while portraying Asian Americans as victims of racial preference. For a progressive response to the problems posed by interethnic conflict in the context of affirmative action, see Lawrence \& Matsuda, supra note 10, at 178-202 (addressing, in part, the complex relationship between Asian Americans and affirmative action); see also Neil Gotanda, Asian American Rights and the "Miss Saigon Syndrome," in Asian Americans and the Supreme Court 1087, 1087-91 (Hyung-Chan Kim ed., 1992) (denouncing the "model minority" myth of Asian Americans, used to both deny the existence of serious discrimination against Asian Americans and as a racist tool to blame African Americans for their relative "failure" compared to Asian Americans); Mari J. Matsuda, We Will Not Be Used: Are Asian Americans the Racial Bourgeoisie?, in Where is Your Body? And Other Essays on Race, Gender, and the Law 149, 153-54 (1996) (urging Asian Americans to resist playing the "racial bourgeoisie" role by failing to support affirmative action and calling on Asian Americans, instead, to support such programs).

56. University of California, Introducing the University-Freshman Profile: All Programs Except Engineering at http://ucop.edu/pathways/infoctr/introuc/ prof_except.html (last visited Apr. 12, 2001) (on file with the Columbia Law Review).

57. Comparing applicants to the freshman class admitted for the fall of 1988 with GPAs of 4.0 or higher, African-American, Latino, and Filipino-American students were denied admission at far higher rates than white students. Berkeley admitted $48.2 \%$ of white applicants with GPAs of 4.0 or higher, but only $31.6 \%$ of Filipino-American, $38.5 \%$ of African-American, and $39.7 \%$ of Latino applicants with such GPAs. Rios Complaint, supra note 52 , at 2 .

58. Berkeley admits $50 \%$ of its entering freshman class based on the academic index score alone. The remaining $50 \%$ of the class is admitted based on academics and other factors. In 1996 Berkeley adopted a new admissions policy that included the use of 
in a determinative and exclusionary way on insignificant differences in standardized test scores. ${ }^{59}$

Advanced placement courses are not available in every California high school. According to the lawyers representing the Rios plaintiffs, "As many as twenty-five percent of California's high schools offer no AP courses whatsoever. Yet some high schools-four percent-offered twenty-one or more AP courses. Thus, where a student attends high school plays a very large part in his or her chances of admission to Berkeley." 60 In fact, over fifty percent of Berkeley students come from only five percent of California's high schools. ${ }^{61}$ When the plaintiffs in the Rios case examined the racial makeup of California high schools, they discovered that the higher the concentration of black, Latino and FilipinoAmerican students, the fewer the number of AP offerings. ${ }^{62}$ Prior to

uncapped grade point averages. An uncapped GPA does not place a ceiling on the total number of points a student can receive in the calculation of a weighted GPA. A weighted GPA gives extra points for honors and advanced placement (AP) courses; an "A" in an AP course on a four-point scale is worth five points. 1d. at 11-13. This admissions procedure was further modified in 1998. Now each applicant would be assigned an "academic" score and a "comprehensive" score. The academic score is assigned on a scoring scale of one (highest) to seven (lowest) and is determined based on the admissions readers' assessment of six academic criteria. At least $75 \%$ of the one to seven academic score must be based on three academic criteria: (1) weighted, uncapped GPA, (2) scores on the SAT (or the ACT) and three SAT II tests, and (3) college preparatory courses completed and the level of achievement in those courses, including AP and International Baccalaureate Higher Level (IBHL). Under the 1998 process, applicants could be assigned an uncapped GPA higher than 4.0 if they had taken AP, IBHL, or UC-approved honors courses. Id. UCLA uses the same weighted, uncapped GPA system. Applicants to UCLA in 1998 had an average high school GPA of 4.19 (on a 4.0 scale). See Complaint at I 20, Daniels v. State of California (Cal. Super. Ct. filed Jul. 27, 1999), available at bttp://www.aclu-sc.org/docs/ap-comp.pdf (last visited Apr. 12, 2001).

59. See Rios Complaint, supra note 52, at 13-14; see also Preliminary Results: Fall 1988 Validity Study 5 (on file with the Columbia Law Review) (noting that the existing eligibility indices are "set inappropriately for maximum predictive ability"). For a discussion of the failures of standardized testing as a predictor of performance or success, see Sturm \& Guinier, supra note 47, at 968-97 (noting that standardized tests do not reliably identify those applicants who will succeed in college or later in life); see also Warren W. Willingham et al., Predicting College Grades: An Analysis of Institutional Trends over Two Decades 10 (1990) (finding that school records provide more accurate forecast of freshmen GPAs than do test scores); Michael A. Olivas, Constitutional Criteria: The Social Science and Common Law of Admissions Decisions in Higher Education, $68 \mathrm{U}$. Colo. L. Rev. 1065, 1069-80 (1997) (discussing failure of standardized testing in predicting academic performance of students along racial, ethnic, gender, and age lines); Chris Jenkins, Study Highlights Disparities in LSAT Scores, The Daily Californian, Oct. 29, 1998 (discussing similar findings with respect to LSAT scores of white and minority law school applicants with similar GPAs and educational backgrounds).

60. Kimberly West-Faulcon, NAACP Legal Defense Fund, Press Conference Statement (Feb. 2, 1999) (on file with the Columbia Law Review).

61. Minority Students Sue, supra note 55, at 3.

62. Rios Complaint, supra note 52, at 13; see also Cal. Dep't of Educ., Educ. Demographics Unit, Inequality of Advanced Placement (AP) Opportunity In California Public Schools 2 (on file with the Columbia Law Review) ("African American, Latino and [F]ilipino American public school students have fewer AP opportunities than their white 
1996, the Berkeley admission formula capped GPAs at 4.0, but the current policy uncaps GPAs and assigns an extra grade point for grades achieved in AP courses. ${ }^{63}$ Many of the 750 Latino, black and FilipinoAmerican students with 4.0 GPAs who were denied admission to Berkeley in the fall of 1998 attained the highest possible grades in their school, a rare and remarkable achievement, but they did not stand a chance in competition against a student from Beverly Hills or Palo Alto when the Berkeley admissions policy boosted the other student's straight " $\mathrm{A}$ " average to as much as a 5.0.

The chance to earn a boosted GPA is only the most obvious advantage given to students attending high schools offering AP courses. The student who takes more AP courses has the additional advantage of learning information and practicing academic skills that will significantly increase her chances for higher standardized test scores. Furthermore, the school that offers more AP courses typically has superior resources, such as higher quality of teaching, lower class size, and more books, labs, and computers. ${ }^{64}$

Berkeley also discriminated against the Rios plaintiffs by relying in a determinative way on the SAT. Blacks and Latinos have consistently scored more poorly on these tests than white and Asian-American students. An extensive body of research challenges the usefulness of standardized tests in predicting the performance of poor and minority students, and finds that the SAT does a better job predicting the socioeconomic status of the test taker's parents than predicting college performance. ${ }^{65}$ Yet, SAT scores often become the decisive factor in admis-

counterparts."); Myriam Marquez, Forget Race or Ethnicity; Just Follow the Money to Berkeley, Orlando Sentinel, Feb. 5, 1999, at A14 (noting that "[m]ost schools serving a predominantly minority population offer few, if any, AP courses").

63. See supra note 60 and accompanying text; see also Regents of the University of California, The New Admissions Policy: Thorough, Flexible, Fair (1997), available at http://www.berkeley.edu/news/berkeleyan/1997/1119/admissions.html (last visited Apr. 12,2001 ) (discussing the criteria to be used by the Berkeley admissions committee in the wake of SP-1 and SP-2-the 1995 regents policy to utilize supplemental criteria in admissions in lieu of affirmative action). Criteria included the removal of the cap on GPAs at 4.0, and the unavailability of race and ethnicity as factors for consideration in the admissions process. Prior to this policy change, Berkeley assigned each applicant an academic score and a social diversity score, and then arrayed all of those applicants on the admissions matrix. See Jesús Mena, Impact on Admissions: A Q \& A on Admitting Undergraduates, The Berkeleyan, Aug. 30, 1995, available at http://www.berkeley.edu/ news/berkeleyan/1995/0830/impact.html (last visited Apr. 12, 2001).

64. California schools continue to be plagued by vast disparities in wealth and resources. See Serrano v. Priest, 18 Cal. 3d 728, 768 (1976) (holding that spending disparities based on school district wealth violated the California constitution). For a discussion of continuing inequalities in California public schools despite Serrano, see Hanif S.P. Hirji, Inequalities in California's Public School System: The Undermining of Serrano $v$. Priest and the Need for a Minimum Standards System of Education, 32 Loy. L.A. L. Rev. 583, 596-609 (1999); Martha S. West, Equitable Funding of Public Schools Under State Constitutional Law, 2 J. Gender Race \& Just. 279, 300-13 (1999).

65. See supra note 47 
sions in a competitive environment like Berkeley, where so many applicants have equally excellent high school grades.

Compare the underlying claim of Rios with those of Bowen and Bok and the University of Michigan litigation defense. Bowen and Bok assume the validity and neutrality of "regular" admissions criteria and defend small adjustments in those criteria in the name of diversity. The Rios plaintiffs directly dispute the fairness of criteria such as AP classes and SAT scores and hold the University responsible for perpetuating the discriminatory practices and conditions of the larger society via the use of such criteria. On its face, Rios is a constitutional and statutory challenge to the most obvious manifestations of discrimination in the Berkeley admissions policy, ${ }^{66}$ but by attacking the discriminatory impact of the socalled "color-blind," "merit-based" system, the suit exposes and demands an end to systemic, institutional racial preferences.

The title page of the Rios complaint contains a symbolic reference to the shortcoming of the liberal defense. The Rios lawyers have made subordinated minority children the plaintiffs in the case, placing the victims of racism at the center of the issue. The liberal defense focuses on the benefit to elite institutions and the privileged students who attend them. Anti-affirmative action forces have successfully employed a strategy that appropriates the language of "injury," "victimization," and "rights." This rhetorical move is exemplified in cases such as Bakke and Hopwood where the parties claiming injury are privileged by white supremacy and where the victims of societal racism are rendered invisible by the litigation. The liberal defense fails to directly challenge this conservative tactic. Rather than refute the assertion that affirmative action privileges minorities and victimizes whites, the liberal defense responds by saying, "if affirmative action injures certain white applicants, that injury is justified because white people benefit from affirmative action too." By contrast, Rios directly turns the upside down logic of "reverse discrimination" right side up. The case's caption reflects the reality of racism and gives voice to those who are really on the bottom. ${ }^{67}$ There is more than symbolism in

66. The Rios complaint alleges that the University's current admissions policy reflects impermissible disparate treatment of and has an impermissible disparate impact upon African-American, Latino, and Filipino-American students by denying them an equal opportunity to compete for admission. Rios Complaint, supra note 52, at 15-16.

67. Although minorities are directly affected by the outcome of suits challenging affirmative action programs, courts have often excluded minority participation in these suits brought by white plaintiffs against white institutions. See Alan Jenkins, Foxes Guarding the Chicken Coop: Intervention as of Right and the Defense of Civil Rights Remedies, 4 Mich. J. Race \& L. 263, 282-83 (1999) (citing Hopwood v. Texas, Gratz v. Bollinger, and other cases in which the district courts denied intervention by minorities who sought to defend affirmative action programs); Emma Coleman Jones, Litigation Without Representation: The Need for Intervention to Affirm Affirmative Action, 14 Harv. C.R.C.L. L. Rev. 31, 62-69 (1979); Charles R. Lawrence, When the Defendants are Foxes Too: The Need for Intervention by Minorities in "Reverse Discrimination" Suits Like Bakke, 34 Guild Prac. 1, 5-19 (1976) (discussing the positive impact intervenors representing minorities could have had on Bakke); see also Girardeau A. Spann, Color-Coded Standing, 
this transposition of roles. There is a difference in the substantive claim, a different view of what constitutes equality, a different remedy requested, and, ultimately, a different conception of justice.

The Rios suit reveals a state school system that continues to provide most young people of color with a separate and unequal education. California schools remain segregated in fact, if not by law. Non-white children are concentrated in the worst of those schools. ${ }^{68}$ The Rios plaintiffs' claim that the state's premier university campus replicates and perpetuates a race-based distribution of educational opportunity and privilege by choosing to make the very opportunities denied to black, Latino, and Filipino-American children the prerequisites for admission. No matter how bright and talented Jesus Rios is, and no matter how hard he has worked, he cannot inherit the race and class privilege passed on by parents who can move to wealthy white suburbs or pay for fancy private schools. This suit makes the legal and moral claim that when Berkeley chooses to make inherited privilege the determining criteria of admission, it violates Jesus and Gregory and Justine's rights to equal citizenship. ${ }^{69}$

The day the Rios suit was filed, Berkeley Chancellor Robert Berdahl issued a statement calling the suit's main allegation "false," noting that Berkeley had made significant efforts to realize a diverse student body but that the state's ban on racial preferences limited the University: "We have demonstrated for decades a steadfast resolve to admit and educate students of all races and ethnicities ... Our resolve has not changed. But the laws under which we operate have changed."70

What could the Chancellor have meant when he called the suit's central claim "false"? Was he contesting a factual allegation-saying that the

80 Cornell L. Rev. 1422, 1422-24 (1995) (arguing that current Supreme Court doctrine is racially discriminatory in that it allows white plaintiffs standing to challenge racial inequality in the form of attacks against affirmative action programs but denies standing to minorities seeking to challenge racial discrimination).

68. Public schools in California are approaching "hypersegregation," with more than $40 \%$ of Latino students and $35 \%$ of African-American students enrolled in schools with a 90\% minority population. A 1999 analysis by the L.A. Times indicates that in Los Angeles County alone $59 \%$ of the Latino high school students are in schools where $90 \%$ of the student body is Latino, Asian-American, or black. Analogously, 50\% of the AfricanAmerican students are in schools that are $90 \%$ or more black, Latino, or Asian-American. Richard Lee Colvin, School Segregation 1s Growing, Report Finds, L.A. Times, June 12, 1999, at A1; see also Gary Orfield, The Growth of Segregation: African Americans, Latinos, and Unequal Education, in Susan Eaton \& Gary Orfield, Dismantling Desegregation: The Quiet Reversal of Brown v. Board of Education 53, 66-69 (1996) (discussing similar statistics for other urban areas).

69. To say that Berkeley is legally and morally responsible for its choice to knowingly reproduce the racially discriminatory distribution of educational opportunity created in the state's elementary and secondary school system does not exempt the California public schools from responsibility for correcting those inequalities.

70. Pamela Burdman, Outcry at Universities: Lawsuit Against UC Berkeley Claims "Color-Blind" Admissions Policy is Unjust, S.F. Chron., Feb. 3, 1999, at A13. 
admission policy does not give extra points for AP courses or heavily weigh the SAT in the admissions decision? Or did he make a narrow assertion of legal non-liability-a prediction that, even if the AP policy were proven to have a discriminatory impact, the current Supreme Court would hold that it does not violate Title VI or the Equal Protection Clause? ${ }^{71}$ No doubt the University's lawyers will raise both of those defenses, but I suspect that the Chancellor meant to do more than stake out a narrow legal claim. I think he also made a normative claim-a moral claim if you will-that the University stands on the side of good and right and that it is false to accuse it of racism.

Many faculty members at Boalt Hall must have had a similar reaction to the Trudeau cartoon at the front of this Essay and its implied charge that they too have participated in maintaining institutional racism. They must have thought, "it's unfair to imply that we are a segregated schoolto suggest that we are racists. Look at our record. For years Boalt has had one of the most racially diverse student bodies of all the law schools in the country. We have been in the forefront of the fight to maintain affirmative action. Even with the restrictions of Proposition 209, we have improved our numbers of black and Latino students over the dismal numbers of 1997."

I believe that both the Chancellor's response to the Rios litigation and the reactions that I have attributed to my liberal colleagues at Boalt Hall represent the honest reactions of decent people who are committed to racial justice. ${ }^{72}$ Berkeley's record on this matter does speak for

71. In Bakke five Justices held that, at least with respect to affirmative action, Title VI only prohibits discrimination based on "those racial classifications that would violate the Equal Protection Clause." 438 U.S. at 287; id. at 325 (Brennan, J., concurring). A showing of discriminatory intent is necessary in order to trigger strict scrutiny under the Fourteenth Amendment regardless of whether there is disparate impact. Washington v. Davis, 426 U.S. 229, 239 (1976). This holding of Bakke seemed to conflict with, without expressly overruling, Lau v. Nichols, which held that a showing of disparate impact could constitute a violation of Title VI. 414 U.S. 563, 568 (1974). In Guardians Association v. Civil Service Commission, once again five Justices held that the Title VI regulations implemented by the Department of Education (DOE) prohibiting disparate impact discrimination had the force of law. 463 U.S. 582, 592 (1983); id. at 623 (Marshall, J., dissenting); id. at 644-45 (Stevens, J., dissenting). Given the bare majority in Guardians and the change in composition of the Court since the holding of that case, it remains to be seen whether the Court will continue to defer to the DOE's regulations for implementing Title VI. For further discussion, see Daniel J. Losen, Silent Segregation in Our Nation's Schools, 34 Harv. C.R.-C.L. L. Rev. 517, 534-35 (1999).

72. Philosopher Judith Lichtenberg notes that:

[M] any white Americans ... hold to an ideal of equality . . . [T] [ [and] baffled by charges that we live in a racist society. ... Racism as overt or outand-out racism reflects a powerful strain in our attitudes toward moral responsibility. On this view, you are responsible only for what you intend; tbus, if consciously you harbor no ill-will toward people of another race or background you are in that respect innocent.

Judith Lichtenberg, Racism in the Head, Racism in the World, Report from the lnst. for Pbil. \& Pub. Pol'y, Vol. 12, No. 1, 3 (1992). She contrasts this view held by many people 
itself. ${ }^{73}$ When I measure Boalt Hall's contribution to racial justice by the work of its graduates among my own small circle of valued friends and invaluable colleagues, its impact is impressive. Thelton Henderson, Eva Patterson, Bill Hastie, Tom Williamson, Richard Delgado, John Powell, Dale Minami, Eric Yamamoto, and Angela Blackwell are just some of the extraordinary legal advocates that come immediately to mind. ${ }^{74}$ But the law school's good works do not relieve it, or us, of our moral responsibility for the injustices of the larger society or for the privileges that those injustices afforded us.

The claim in the Rios suit and the Chancellor's response to its charge of discrimination present examples of how different the river of equality looks when viewed from the vantage point of those who are subordinated by America's racism rather than from the vantage point of the privileged. Liberal theory and the liberal jurisprudence that informs most of legal doctrine reflect the perspective of the privileged. By contrast, the Rios

who are privileged by oppression with one that holds "racism is not fundamentally a matter of what is in people's heads or hearts, but rather a function of public institutions and practices that create or perpetuate racial division and inequality." Id.

73. Since 1997, the numbers of minority students admitted and enrolled at Boalt Hall have somewhat improved, but the figures are nowhere near their pre-1997 levels. The numbers of minorities admitted and enrolled at UCLA School of Law have followed a similar pattern, with an especially dismal figure for black enrollment in 1999. In 2000, Boalt Hall admitted 28 black students and 7 enrolled; in 1999, 29 black students were admitted and 7 enrolled; and in 1998, 32 black students were admitted and 8 enrolled. In 2000, 63 Latino students were admitted and 18 enrolled; in 1999, 57 Latino students were admitted and 16 enrolled; in 199860 Latino students were admitted and 23 enrolled. By contrast, in 1996, 77 black students were admitted of whom 20 enrolled, and 85 Latino students were admitted, of whom 45 enrolled. University of California's Law Schools, supra note 2.

Meanwhile, in 2000, UCLA School of Law admitted 13 black students and 5 enrolled; in 1999, 19 black students were admitted and 3 enrolled; in 1998, 18 black students were admitted and 8 enrolled. The Latino student population has experienced a similar decline in representation. In 2000, 72 Latino students were admitted and 28 enrolled; in 1999, 58 Latino students were admitted and 18 enrolled; in 1998, 47 Latino students were admitted, and 16 enrolled. By contrast, in 1996, 104 black students were admitted of whom 19 enrolled, and 108 Latino students were admitted, of whom 45 enrolled. Id.

74. Thelton Henderson is Chief Judge of United States District Court for the Northern District of California. Eva Patterson is the Executive Director of the Lawyers' Committee for Civil Rights of the San Francisco Bay Area, and Co-Chair of Californians for Affirmative Action. Bill Hastie was one of the founding attorneys of Public Advocates as well as of Arnelle \& Hastie, at one time the second-largest black law firm in the country. Tom Williamson is the second African-American to become a partner at Covington \& Burling; he was Solicitor of Labor from 1992-1996. Richard Delgado is a Jean Lindsley Professor of Law at the University of Colorado School of Law, and a noted critical legal scholar. John Powell is a Professor of Law at the University of Minnesota Law School and Executive Director of the Institute on Race and Poverty. Dale Minami is a founding member of the Asian Law Caucus and was a key figure in procuring reparations for Japanese-Americans interned by the federal government during the Second World War. Eric Yamamoto is Professor of Law at the University of Hawaii Law School. Angela Blackwell is the President and founder of Policy Link, a national institution devoted to advancing policies and practices that improve low-income communities. 
suit is grounded in antisubordination theory, a theory that takes the vantage point of those who are victimized by societal racism.

Liberal theory focuses on guarding the liberty of an autonomous, disconnected human being. 1t holds that "power should be exercised in accordance with the rule of law, that government should recognize and respect rights, and that freedom, rather than equality, should be the highest political value." 75 Liberal legality sees the equality principle as primarily concerned with protecting individuality, and views racial discrimination as unjust because when we judge a person based on her race we disregard her unique human individuality. For the liberal legal theorist, racism consists of isolated prejudicial discriminatory practices in an otherwise nondiscriminatory world. Identifiable perpetrators who have purposefully or intentionally caused harm to identifiable individual victims violate the moral and constitutional command of equality, not historical or institutional conditions of group subordination. The Chancellor's denial reflects this narrow definition of harm and culpability. The charge of racial discrimination is deemed false. While there may be unfortunate conditions of inequality in the world, Berkeley cannot be held responsible for them. The perspective of the privileged denies history. It makes an abstract moral claim to equal treatment unsullied by history or social reality. ${ }^{76}$

Like the Berkeley chancellor's response to the Rios suit, the liberal defense of affirmative action is grounded in liberal theory. Rather than defend affirmative action as necessary to insure equal opportunity in a world where a variety of social structures, institutional practices, and unconscious racist beliefs conspire to deny minorities equal consideration and respect, the liberal defense justifies diversity as a way to help privileged whites better understand people of color in a nation that may soon have a non-white majority. This social utility argument leaves in place our current measures of merit and defends minor adjustments in those measures because racial integration of elite universities and professions will benefit the community as a whole.

Critics of liberal theory, including critical race theorists, have offered another way to think about promoting equality and human dignity, one

75. Austin Sarat, Going to Court: Access Autonomy and the Contradictions of Liberal Legality, in The Politics of Law: A Progressive Critique 97, 97-111 (David Kairys ed., 3d ed. 1998); see also Roberto Unger, Law in Modern Society: Toward a Criticism of Social Theory 176-81 (1977) (describing and expressing skepticism towards liberal theory's account of the relationship between autonomy and the rule of law); Robin West, Caring for Justice 4 (1997) (criticizing mainstream liberal theory for emphasizing individual autonomy over "the connections that sustain and enlarge us").

76. See generally Alan David Freeman, Legitimizing Racial Discrimination Through Antidiscrimination Law: A Critical Review of Supreme Court Doctrine, 62 Minn. L. Rev. $1049,1052-54$ (1978) (arguing that civil rights law in the twenty-five years after Brown has served more to rationalize the continuing effects of discrimination than to produce any genuine liberation from race and class oppression). 
that reflects the perspective of the subordinated. ${ }^{77}$ Consider the constitutional and moral command of equal protection as one requiring the elimination of society's racism rather than mandating equal treatment as an individual right. Critical race theorists have called this theory "substantive equality" or "antisubordination" theory. Such a substantive approach assumes that ridding society of racial subordination is indispensable and a prerequisite to individual dignity and equality. It understands that white supremacy continues to exist and hurts us all. ${ }^{78}$ Critical race theory focuses on the persistence of conditions created by and traditionally associated with racist practice. Racism as traditionally practiced led to discriminatory exclusions from employment, from "white" neighborhoods, from politics, from government contracts, and from universities like Texas, Michigan, and Berkeley. If those same conditions of exclusion exist in virtually identical form after antidiscrimination laws have prohibited overt racial discrimination, the law has not yet done its job. From the perspective of those who are subordinated, those conditions are presumptive violations. The Rios suit speaks from the vantage point of the subordinated. The Trudeau cartoon asks the reader to see Boalt Hall through the same lens. The absence of blacks should be treated for moral purposes as intentional. "We no longer admit black people."

The original vision of affirmative action proceeded from the perspective of the subordinated. The students and community activists who fought for affirmative action in the 1960s and '70s understood that racism operated not primarily through the acts of prejudiced individuals against

77. See Ruth Colker, Anti-Subordination Above All: Sex, Race, and Equal Protection, 61 N.Y.U. L. Rev. 1003, 1007 (1986) (arguing for an anti-subordination perspective that utilizes a group-based approach to eliminate the power disparities between wbites and nonwhites and between men and women as it is "inappropriate for certain groups in society to have subordinated status because of their lack of power in society as a whole"); Kimberlé Williams Crenshaw, Race, Reform, and Retrenchment: Transformation and Legitimation in Antidiscrimination Law, 101 Harv. L. Rev. 1331, 1336 (1988) (suggesting the need to move beyond existing antidiscrimination law as it has allowed black material subordination to be perpetuated, and because we need to make a "societal commitment to the eradication of the substantive conditions of Black subordination"); see also Freeman, supra note 76, at 1118 (making the case for the subordinated group through what he calls the "victim perspective"). See generally bell hooks, Feminist Theory from Margin to Center (1984) (arguing that viewing society and life from the "margin" provides important insights not available to those viewing society from the center).

78. Elsewhere 1 have contrasted this transformative or substantive approach to racial equality with that of liberal individualist theory:

The substantive approach sees the disestablishment of ideologies and systems of racial subordination as indispensable and prerequisite to individual human dignity and equality. The nonsubstantive approach sees the individual right to be treated without reference to one's race as primary. ... [E] ach approach defines the injury of racism differently. The theory that places the right with the individual likewise sees the injury as one suffered by individuals. The theory that seeks societal transformation sees the injury as done to the collective, as suffered by us all.

Lawrence, Multiculturalism, supra note 51, at 824-25. 
individuals of color but through the oppression of their communities. It was not enough to remove the "White" and "Colored" signs from lunch counters, buses, and beaches. Institutionalized racism operated by denying economic resources, education, political power, and self-determination to communities of people defined by race. ${ }^{79}$ When they demanded affirmative action-when they sat-in and sued and took over buildings and went on hunger strikes and closed down universities-they sought redress for their communities. Their demand for affirmative action was part of a broad vision of a just university. They demanded an end to university expansion that forced poor people out of housing. They sought courses and research that addressed community needs. They demanded the admission of students and the hiring of faculty who identified with the excluded-not just people who shared their skin color or language, but individuals who would represent and give voice to those persons who were ignored, misrepresented, or objectified in traditional scholarship. ${ }^{80}$ Many of today's progressive student activists share the vision that guided affirmative action's radical advocates a generation earlier. The students organizing to repeal the anti-affirmative action amendment in California and those who have intervened in the Michigan case want more than the reinstitution of liberal affirmative action. They are demanding that universities discontinue practices that reinforce societal discrimination and act affirmatively to alleviate conditions of poverty and human suffering in communities of color.

The liberal defense of affirmative action does more than buttress the structure of race and class subordination. It also participates in the production of an ideology that justifies the re-segregation of the academy in the name of equality. Justifications for affirmative action are often divided into two main types. Arguments that focus on past and continuing discrimination against minorities, women and other groups are often called "backward-looking." They argue for affirmative action to make amends for or to rectify the effects of past injustices. By contrast, "forward-looking" arguments for affirmative action make sparing reference to past or current wrongdoing, and instead defend affirmative action as a means to some desirable future goal. ${ }^{81}$ The liberal or "diversity" defense

79. See Lawrence \& Matsuda, supra note 10, at 13, 17.

80. For a description of the historical origins of this more radical vision of affirmative action and an account of the student movement that resisted the backlash against affirmative action, see id. at 11-58.

81. See Kathleen M. Sullivan, Sins of Discrimination: Last Term's Affirmative Action Cases, 100 Harv. L. Rev. 78, 80 (1986) (arguing that Supreme Court has only approved affirmative action as remedy for past discrimination, but has refused to justify it as path to racially integrated future). For an influential version of the forward-looking approach, see Ronald Dworkin, Taking Rights Seriously 32 (1978). For an argument sharply critical of the forward-looking approach, see 2 George Sher, Diversity, Philosophy \& Public Affairs 28 (1999) (arguing that the advantages of "forward looking" justifications for "preferential treatment" are "illusory" in that they turn on "tacit appeals to past wrongdoing"). For an argument that the most coherent and defensible justification of affirmative action is both 
articulates its purpose as "forward-looking" rather than "backward-looking." ln so doing, it begins with an implicit denial of the defender's participation in or responsibility for past or contemporary racism. The university seeks to prepare its students for future participation and leadership in a racially diverse society and expresses no interest in reparations. By looking only forward, it avoids any direct admission or acknowledgement of the institution's past discriminatory practices, ${ }^{82}$ even when that discrimination is de jure and of relatively recent vintage ${ }^{83}$ It makes no effort to inquire into the ways that current facially neutral practices may have a foreseeable and unjustifiable discriminatory impact or to account for unconscious bias in their administration. ${ }^{84}$ This denial concurs in and reiterates "the big lie, ${ }^{85}$ the anti-affirmative action argument that pretends that white supremacy is extinct and presupposes a color-blind world, a world in which race-conscious remedies become invidious dis-

forward-looking and backward-looking, see Lawrence, Race and Affirmative Action, supra note 9 , at $765-66$.

82. By denying past and present discrimination, the university also gives up its strongest legal defense to a reverse discrimination claim. See Richard Delgado \& Jean Stefanic, California's Racial History and Constitutional Rationales for Race-Conscious Decision-Making in Higher Education, 47 UCLA L. Rev. 1521, 1529-30 (2000) (asserting that the rationale for affirmative action as a way to remedy past discrimination still survives Hopwood, but evidence of past discrimination must be specific and particularized); Daria Roithmayr, Deconstructing the Distinction Between Bias and Merit, 10 La Raza L.J. 363, 412 (1998) (asserting that evidence of past discrimination in law school admissions and institutional history of discrimination can demonstrate compelling state interest in remedying past discrimination).

83. See, e.g., Hopwood v. Texas, 861 F. Supp. 551, 554-57 (W.D. Tex. 1994) (documenting history of de jure segregation in educational system in Texas, from its resistance to integration polices demanded by Brown, to more recent decision in 1983 in which the District Court of Columbia ruled in a Title VI enforcement suit that "Texas has still not committed itself to the elements of a desegregation plan which in the defendant's judgment complies with Title VI"). In 1994, the Office of Civil Rights continued to oversee Texas's efforts to "eliminate all effects of de jure segregation." Id. at 557.

84. See, e.g., William C. Kidder, The Rise of the Testocracy: An Essay on the LSAT, Conventional Wisdom, and the Dismantling of Diversity, 9 Tex. J. Women \& L., 167, 169-71, 217-18 (2000) (arguing that conventional definition of test bias-the "linear regression model" - can actually mask bias by relying on criterion (law school grades) that also may be contaminated by bias against women, people of color, and other outsider groups); Olivas, supra note 59, at 1069-74 (arguing that common admissions practice of reliance on test scores is not an objective or race-neutral process); see also Ass'n of Am. Law Schs., Perspectives on Diversity: AALS Special Commission on Meeting the Challenges of Diversity in an Academic Democracy (1997) (on file with the Columbia Law Review) (discussing "second-generation" diversity issues); Sturm \& Guinier, supra note 47, at 958 (suggesting that underlying current selection and admissions processes may not function fairly for anyone, and urging a new dialogue using race- and gender-based inquires to rethink selection measures as a whole). Intervenors in the University of Michigan litigation cite several studies documenting the continuing racial isolation and hostile environment faced by students of color and women at Michigan and other colleges and universities. See Memorandum in Support of Motion to Intervene at $9 \mathrm{n} .14$, Grutter v. Bollinger, 16 F. Supp. 2d 797 (E.D. Mich. 1988) (No. 97-CV-75928-DT).

85. Lawrence \& Matsuda, supra note 10 , at $69-87$. 
crimination. ${ }^{86}$ Unlike those who perpetrate the big lie in order to justify their opposition to affirmative action, the liberal defenders do not expressly deny the presence of past or current racial discrimination. Instead they claim disinterest in either, arguing that it is more fruitful and less divisive to focus on the future than to stir the ashes of a troubled past. But the effect is much the same. The liberal defense is framed as if there is no structural discrimination to remedy. It does not challenge the fairness or rationality of conventional selection processes or standards of merit. Instead, it tells a story of a foresighted university committed to integration for the sake of diversity, not corrective justice. It is a defense that begins on the day the affirmative action policy was initiated, ignoring the university's long history of de jure and de facto segregation; ${ }^{87}$ segregation that continued until disruptive student protests and the fires of urban rebellions forced a change. 88

It is this implicit participation in the big lie that allows liberal faculty at Berkeley, UCLA, and Texas to see themselves as fully committed to affirmative action, even as they throw up their hands and say, "We are helpless" in the face of Proposition $209^{89}$ and the Fifth Circuit's decision

86. See City of Richmond v. J.A. Croson Co., 488 U.S. 469, 480 (1989) (holding that there was "no direct evidence of race discrimination" against minority subcontractors).

87. The District Court in Hopwood found that as recently as 1960 , the University of Texas had segregated Mexican-American students in campus housing and assigned them to a dormitory known as "the barracks," and that until the mid-1960s, a Texas Board of Regents policy prohibited blacks from living in or visiting white dorms. $861 \mathrm{~F}$. Supp. at 555.

88. See Lawrence \& Matsuda, supra note 10, at 18-29 (discussing the role of student protest and urban uprisings in motivating universities to initiate affirmative action programs).

89. Although university faculty claim that their hands are tied by court orders and legislation barring the use of race in admissions, they have also demonstrated a reluctance to aggressively pursue alternatives aimed at maintaining racially diverse student bodies. For example, in May of 1997, in the wake of Proposition 209, a group of nine Berkeley law and graduate students authored a report and proposal which critiqued the current admissions policy at Boalt Hall and offered an alternative admissions strategy designed to bring students of diverse backgrounds to the law school. Cecilia U. Estolano et al., New Directions in Diversity: Charting Law School Admissions Policy in a Post-Affirmative Action Era (May 9, 1997) (on file with the Columbia Law Review). The proposal called for a four step plan to correct the inequities in Boalt's existing admissions policies: 1) the creation of a "Character lndex" that "would include variables to measure an applicant's individual attributes, such as family wealth and parental education as well as neighborhood factors, such as poverty rates and the educational attainment of an applicant's high school peers"; 2) the integration of alumni interviews in the admissions process; 3) greater outreach to underrepresented communities; 4) the elimination of hidden preferences by using race to measure "experiential diversity." ld. at i-iii. This final policy was framed as a remedy to the disparate impact on people of color and preference to whites that is occasioned by Boalt's heavy reliance on the LSAT. Id. at 67-71. The Boalt faculty rejected the proposal, arguing that it would be held unlawful by the courts. They also rejected the alumni interview proposal despite an offer by the San Francisco Bar Association to fund all costs, recruit alumni interviewers, and administer the program. Telephone Interview with Drucilla Ramey, Director, San Francisco Bar Association (June 15, 2000). 
in Hopwood. ${ }^{90}$ So long as university faculties remain indifferent to the continuing legacy of their own past discriminatory practices or the ways in which current admission policies unjustifiably reinforce contemporary racial discrimination, they need not face up to their own active participation in the maintenance of race and class privilege.

For example, when Grutter v. Bollinger, the suit challenging the University of Michigan Law School's affirmative action program, was first filed, many people encouraged the University to admit and carefully document its own historical and contemporary discrimination against African-Americans and other minority students. ${ }^{91}$ This seemed the University's safest and most straightforward strategy. The Court's opinions in City of Richmond v. J.A. Croson Co. ${ }^{92}$ and Adarand v. Pena ${ }^{93}$ had made it clear that the remedy of identified past and continuing discrimination was a compelling state interest and that a racial classification, narrowly drafted to serve that interest, would survive strict scrutiny. ${ }^{94}$ The fate of

90. Hopwood v. Texas, 78 F.3d 932 (5th Cir. 1996); see supra note 89 (describing how faculties have rejected race-neutral alternatives that might have maintained level of minority admissions).

91. See, e.g., Kerry Colligan, Panelists Discuss History of Affirmative Action, Lawsuit, Univ. Rec., Nov. 26, 1997, at 6 (reporting on part of a student-sponsored, four-evening symposium entitled, "Affirmative Action 101: Understanding the Controversy," at which a panelist argued that affirmative action is necessary to "compensate for a history of slavery and systemic racial discrimination"); Bernie DeGroat, AAAJS Affirmative Action March, Diag Rally Draw Students, Faculty, Staff, Univ. Rec., Jan. 28, 1998, at 6 (reporting on rally on the University of Michigan campus at which faculty members called upon demonstrators to fight for affirmative action to combat institutional racism endemic to our society); Paula Saha, Panel Presents Perspectives on Diversity in Higher Education, Univ. Rec., Nov. 26, 1997, at 6 (reporting on "Affirmative Action 101: Understanding the Controversy," at which panelist Earl Lewis, University of Michigan Professor of History and of Afro-American and African History and lnterim Dean of the Graduate School, argued that "history matters," and history is a supportive rationale for affirmative action programs).

92. 488 U.S. 469, 470-74 (1989) (striking down Richmond's plan requiring prime contractors awarded city construction contracts to sub-contract at least $30 \%$ of the dollar amount to one or more minority business enterprises).

93. 515 U.S. 200, 227 (1995) (holding that federal program designed to provide highway contracts to disadvantaged business enterprises must withstand strict scrutiny).

94. The majority in Adarand held:

The unhappy persistence of both the practice and the lingering effects of racial discrimination against minority groups in this country is an unfortunate reality, and government is not disqualified from acting in response to it. ... When racebased action is necessary to further a compelling interest, such action is within constitutional constraints if it satisfies the "narrow tailoring" test this Court has set out in previous cases.

Id. at 237. In Croson, the Court held, "Thus, if the city could show that it had essentially become a 'passive participant' in a system of racial exclusion practiced by elements of the local construction industry, we think it clear that the city could take affirmative steps to dismantle such a system." Croson, 488 U.S. at 492; see also Delgado \& Stefancic, supra note 82, at 1529-30 (arguing that as a result of Croson, plaintiffs claiming discrimination in higher education settings will have to demonstrate via evidence with "high credibility" that "past discrimination [was] specific and particularized, not merely societal and general"); 
the diversity defense standing alone was at best unsettled. ${ }^{95}$ The University's strongest case was one that combined the remedial justification with the diversity defense. ${ }^{96}$ The University rejected this suggestion, relying instead on the diversity defense alone.

Perhaps the University's rejection of the remedial defense can be explained by its concern that by admitting its own discriminatory practices it would expose itself to liability vis-a-vis minority applicants and students. ${ }^{97}$ However, many cities and governmental agencies have adopted a preemptive approach to defending affirmative action programs by carefully documenting the continuing effects of their past discriminatory practices. ${ }^{98}$ As noted earlier, the Supreme Court has implicitly, if not

Roithmayr, supra note 82, at 412 (arguing that broad remedial affirmative action in admissions policies may be possible "on grounds that the selection process itself is intrinsically and structurally discriminatory").

95. See Corinne E. Anderson, A Current Perspective: The Erosion of Affirmative Action in University Admissions, 32 Akron L. Rev. 181, 203-05 (1999) (arguing that Hopwood decision is illustrative of lack of judicial restraint, as the Fifth Circuit prematurely overruled Justice Powell's diversity rationale in Bakke and "ignored the special consideration the Supreme Court has traditionally accorded education," by relying on precedents that are not related to education); Akhil Reed Amar \& Neal Kumar Katyal, Bakke's Fate, 43 UCL.A L. Rev. 1745, 1768 (1996) ("The Court ... [has] nowhere explicitly overruled Bakke, and so, under well established general principles, it clearly remains binding precedent for all lower courts, state and federal."); Jim Chen, Diversity and Damnation, 43 UCLA L. Rev. 1839, 1851 (1996) (noting the Fifth Circuit's "startling rejection of prevailing legal wisdom" in holding that "diversity as a governmental interest is not sufficiently compelling to justify race-conscious law school admissions").

96. The intervenors suggest that the Regents of the University of Michigan are permitted under the Fourteenth Amendment to use race-conscious admissions "to remedy ... the continuing effects of past discrimination that [the University] has caused and its own current discrimination," as well as to further "a compelling interest in diversity." Defendant-Intervenor's Response in Opposition to Plaintiffs' Renewed Motion for Summary Judgment at 4, 2, Gratz v. Bollinger, 183 F.R.D. 209 (E.D. Mich. 1998) (No. $97-$ CV-75231-DT). However, the University's defense rests solely on Justice Powell's diversity rationale, leaving out a potentially powerful defense tool. Defendant's Answer at I 18, 19, 22, Gratz v. Bollinger, 183 F.R.D. 209 (E.D. Mich. 1998) (No. 97-CV-75231-DT).

97. See Motion to Intervene at I 18, Gratz v. Bollinger, 183 F.R.D. 209 (E.D. Mich. 1998) (No. 97-CV-75231-DT) (pointing out that although race-conscious action could be upheld on remedial grounds, providing the necessary evidence might be in tension with the University's interest in avoiding liability for discrimination). In United Steel Workers of Am. v. Weber, 443 U.S. 193 (1979), Justice Blackmun noted the "catch-22" faced by defendants in anti-affirmative action cases. "[O]n the one hand they face liability for past discrimination against blacks, and on the other they face liability to whites for any voluntary preferences adopted to mitigate the effects of prior discrimination against blacks." Id. at 210 (Blackmun, J., concurring).

98. More than 140 state and local jurisdictions have commissioned "disparity studies" used to justify their Minority Business Enterprise (MBE) ordinances since the Croson decision. George R. La Noue, Who Counts? Determining the Availability of Minority Businesses for Public Contracting After Croson, 21 Harv. J.L. \& Pub. Pol'y 793, 797-805 (1998) (also discussing the effectiveness of disparity studies and other methods jurisdictions could employ to justify MBE ordinances). See generally George R. La Noue, Minority Business Programs and Disparity Studies: Responding to the Supreme Court's 
expressly, indicated its own approval of such an approach. ${ }^{99}$ The University's reluctance to admit past and present discrimination is better explained by the faculty's and administration's reluctance to examine and admit their own participation in racism and to give up the advantages the current system affords them. ${ }^{100}$

By contrast, the underlying moral claim of the Civil Rights Movement ${ }^{101}$ and of the demand for affirmative action that grew therefrom, contested the university's historic role as palace guard for the power elite. ${ }^{102}$ It challenged the university to make racial justice central to its mission and to expand its constituency to include those most in need. Great universities like Yale, Chicago, and Columbia were asked to look out at the blocks surrounding their campuses, where human suffering and urban decay stood as a challenge to the greatest intellects of the day: Will you stand by in silence or will the university become a place of intellect committed to justice? Many liberals first supported affirmative action in response to that moral challenge. They understood its threat to their privilege, and, nonetheless, were persuaded by the moral imperative of the more radical claim for equality. 1 think the current liberal defense is not a rejection of that once tentatively embraced moral claim, but a back-

Mandate in City of Richmond v. Croson (1994) (providing a discussion of and step-by-step guide to commission, completion, and use of a disparity study).

99. See Adarand, 515 U.S. at 237 (1995); Croson, 488 U.S. at 492 (1989). But see Hopwood v. Texas, 78 F.3d 932, 955 (5th Cir. 1996) (holding that a law school may not take race into account in admissions despite evidence of significant past and ongoing discrimination against minorities in the state's educational system); Podberesky v. Kirwan, 38 F.3d 147, 161 (4th Cir. 1994) (striking down use of race-based scholarships because evidence of minority underrepresentation, low retention rates of minority students, and hostile racial campus environment did not sufficiently show present effects of past discrimination).

100. The offspring of university faculty are particularly advantaged in the current admissions structure. The children of academics who grow up surrounded by books and adults who are part of an intellectual community are even more likely to do well on SATs and advanced placement tests than the children of wealthier parents who are not academics.

101. 1 use the term "Civil Rights Movement" here to refer to the larger liberation movement among subordinated people of color in the United States for political selfdetermination and control of resources within their own communities as well as for access to institutions of power and influence such as universities. For an account of the history of affirmative action's origins in the Civil Rights Movement, see Lawrence \& Matsuda, supra note 10 , at $11-40$.

102. See C. Wright Mills, The Power Elite 62-70 (1956) (discussing role of elite educational institutions as custodians and curators for the traditions of the wealthy, ensuring the smooth transfer of social and political power to the sons and daughters of the privileged); see also Roithmayr, supra note 82, at 389-93 (describing how law school admission standards have historically denied immigrants and persons of color entry into legal profession, and asserting that the same intentionally biased standards still dominate the practice today); David M. White, The Definition of Legal Competence: Will the Circle Be Unbroken?, 18 Santa Clara L. Rev. 641, 648-49 (1978) (discussing how law school and bar examination criteria act as exclusionary measures to limit access to the practice of law, leaving bar composed primarily of affluent white males). 
sliding in the name of pragmatic politics. 1t is a backsliding rationalized by the doctrine of formal equality. In a world where law is increasingly made on the premise that the market produces just results, it is easy to forget that we are all our brothers' and sisters' keepers. ${ }^{103}$

Ultimately, by failing to examine how conventional procedures and standards for admissions reinforce race and class subordination, the liberal defense leaves unchallenged a definition of the university's primary mission as gatekeeper for and producer of a professional elite. This failure to address systemic racism leaves the liberal defense with an inadequate response to the central criticisms of affirmative action. Emphasizing the importance of diversity conveniently sidesteps the debate over whether our institutions are truly meritorious. By avoiding that question, the diversity defense remains vulnerable to the right-wing attack that affirmative action endangers the continuing success of our schools by substituting for fairness and hard work a principle of vague importance.

\section{I. A Critical Race Theorist's Dilemma}

How should a critical race theorist respond to the liberal defense of affirmative action? Can it be reconciled with the more radical "original vision" that I describe above? ${ }^{104}$ Is there no common ground upon which liberal and radical defenders of affirmative action can meet and join forces?

Certainly, strong strategic reasons for supporting the liberal defense of affirmative action exist. In the short run, Bowen and Bok have charted the course that will most likely succeed in today's judicial and political climate. ${ }^{105}$ If there is any hope that the current Supreme Court will up-

103. See, e.g., Robin West, Law, Rights, and Other Totemic lllusions: Legal Liberalism and Freud's Theory of the Rule of Law, 134 U. Pa. L. Rev. 817, 845-872 (1986) (criticizing law and economics movement's proposition that individual desire to maximize wealth is benevolent and poses no moral or social dangers).

104. Elsewhere 1 have referred to this more radical vision as the "deep meaning" of affirmative action. See Lawrence, Harvest, supra note 13, at 775-78 (acknowledging that diversity in education benefits everyone affected, but also criticizing the diversity argument for failing to see that the "forward-looking" benefit of affirmative action must also be informed by historical and contemporary racism); Lawrence \& Matsuda, supra note 10, at 26-29.

105. Current Supreme Court doctrine requires that any affirmative action program be "narrowly tailored to remedy the effects of prior discrimination" in order to survive strict scrutiny. City of Richmond v. J.A. Croson Co., 488 U.S. 469, 507 (1989). Generalized assertions of past discrimination would not be enough to justify an affirmative action policy. Litigants defending affirmative action would have to point to specific discriminatory policies and procedures that had an adverse impact on minorities. 1d. at 498. In this context, a diversity defense of affirmative action would seem doomed to fail, except that as Professors Akhil Amar and Neal Katyal have pointed out, Justices O'Connor and Kennedy may take a different approach to affirmative action in the educational context were the Court to revisit Bakke. See Amar \& Katyal, supra note 95, at 1769-71. Though they have elsewhere expressed opposition to affirmative action, both Justices O'Connor and Kennedy take caution to uphold precedent. Id. In addition, Amar and 
hold a race-conscious university policy-whether in admissions, scholarships, or the employment of faculty-it lies in persuading the center of the Court that it can trust university faculties and administrators to determine how best to maintain America's premier academic institutions and, implicitly, the existing elite-school power and privilege that has served people like the justices themselves. Institutional autonomy lies at the center of Justice Powell's opinion in Bakke. The opinion's doctrinal reasoning sounds in the First Amendment right to speech and academic freedom, ${ }^{106}$ arguing that the judiciary must grant faculties autonomy in making admissions decisions in order to preserve academic autonomy of thought. ${ }^{107}$ Powell understood that an educated elite who shared his values and sense of nobless oblige would exercise this autonomy. ${ }^{108}$ Powell's Bakke opinion contains a subtext that reads roughly as follows: "We must integrate the university because lily-white institutions will lose legitimacy among excluded groups, with potentially destabilizing consequences for a democratic system. Future elites must learn to govern in an increasingly diverse society and an increasingly globalized, largely nonwhite world. University faculties occupy the best position to determine whether and to what extent schools require the admission of minorities and to decide which minorities are best suited to serve the important purpose of maintaining the status quo." The risk of a Supreme Court decision that abandons Bakke and prohibits any use of race-sensitive affirmative action in the academy is hardly trivial. I have criticized Justice Powell's reasoning for its conservatism, but its rationale will likely prove most attractive to the current Supreme Court. For this reason alone it should not be lightly set aside.

The liberal defense of affirmative action provides the best legal strategy precisely because it promises most effectively to preserve the status quo. It is also true that the status quo under current affirmative action regimes has much worth preserving. I know, for example, that I have a significant personal stake in the world liberal affirmative action has cre-

Katyal believe that as long as affirmative action in tbe educational context is based on race as one consideration among many, as opposed to a rigid quota, the Court may be willing to recognize that diversity in education is a compelling interest and a positive end in itself. Id. at 1772-79; see also Lawrence, Harvest, supra note 13, at $764 \mathrm{n} .27$ (critiquing "Amar and Katyal's otherwise powerful argument" because it does not recognize that "our nation's historical and contemporary racism must be a primary subject of our conversation").

106. See Lawrence, Harvest, supra note 13 , at $770-71$

107. See J. Peter Byrne, Academic Freedom: A "Special Concern of the First Amendment," 99 Yale L.J. 251, 314-16 (1989) (arguing that Justice Powell's reliance on the First Amendment is supported by a strong tradition of academic autonomy in the pursuit of educational goals and is not merely an attempt to provide an acceptable way to preserve affirmative action while condemning racial preferences). But see Lawrence, Harvest, supra note 13, at 770-75 (critiquing Justice Powell's First Amendment argument).

108. For a discussion of how Archibald Cox reminded the justices of their shared membership in an educational elite during his oral argument in Bakke, see Joel Dreyfuss \& Charles Lawrence III, The Bakke Case: The Politics of lnequality 172-202 (1979). 
ated. ${ }^{109}$ I have come to count on the enriching experience of teaching classes in which African-American, Latino, Asian-American, and white students do the hard work of learning from and about one another. ${ }^{110}$ I know that many of the bright young people of color who have been my best students were admitted to law school under the very affirmative action programs I have criticized as elitist. The law schools where I have taught considered them attractive candidates because their experience as subordinated minorities served the faculty's pedagogical interest in a "robust exchange of ideas," and, perhaps even more importantly, because these individuals had, somewhere along the way, acquired the skills and sensibilities that only come from access to privilege. ${ }^{111}$

I want to convey the full complexity of my dilemma. I have criticized the liberal defense of affirmative action as a means of entrenching a privileged elite, but the increased racial integration of the new elite class and of elite institutions is a significant social achievement. Diversity can be defended on moral and ethical grounds because it produces a positive good rather than being merely instrumental to the end of antisubordination. In a racially integrated classroom or university community we get to

109. The world I refer to here is that of the relatively elite Iaw schools where I have taught during the past fifteen years (Stanford, Georgetown, Harvard, USC, UCLA, and Berkeley). These law schools, and other comparable schools, have realized racially diverse student bodies and somewhat less diverse faculties under the affirmative action policies and practices that have resulted from and are defended by the liberal argument I describe in Part I. For a discussion of how the ideal of affirmative action as a vehicle for community power was transformed to a mechanism for co-optation, see Lawrence \& Matsuda, supra note 10 , at $24-26$.

110. I have omitted the mention of American-lndian students here in the interest of accuracy. In twenty-five years of teaching at seven different law schools I have taught only three American-Indian students. My experience reflects the overall data on AmericanIndian enrollment in American law schools which can only be described as bleak. For example, last year at Boalt Hall American Indians represented only .5\% of those students enrolled on a full time basis. UCLA did not fare any better, with American Indians representing .5\% of its enrollment. Rick Morgan \& Kurt Snyder, Official American Bar Association Guide to Approved Law Schools 116-23 (2000).

111. The irony of defending affirmative action at elite law schools like Boalt Hall and Michigan is that there is really very little affirmative action to defend. The attack on affirmative action is premised on the assertion that unqualified minorities are being preferred over whites with superior qualifications, but the bottom line of the data in Bowen and Bok's study is that the best schools simply do not sacrifice the "quality" of their students to achieve racial integration. See Bowen \& Bok, supra note 25, at 100-02. I am always struck by how many of the black students I encounter at the best law schools have also attended elite undergraduate institutions. Not all of these students come from families who are privileged by class or education, but almost without exception they have had the good fortune of finding their way to educational institutions where the sons and daughters of the privileged are educated. The criticism that race-based affirmative action only benefits the most privileged minorities is one that is often made by opponents of affirmative action. For a discussion calling for an expansion of affirmative action to include those who are subordinated by poverty while retaining important elements of affirmative action directed at remedying racism, see Lawrence \& Matsuda, supra note 10 , at 178-202. 
know people who are different from ourselves as whole people. When we form close and enduring friendships with individuals who are unlike ourselves, we further an ethic of humanity and human connection. Affirmative action has made law schools different and better places. The University of Michigan defends its affirmative action program by demonstrating that a racially diverse campus is essential to the education of students who have grown up in racially segregated communities and who come to college with few friends of other races. ${ }^{112}$ This argument is compelling even in the context of privilege. Students of color who are privileged by class or educational background nonetheless experience subordination by ubiquitous societal racism. ${ }^{13}$ They bring to the classroom and to the larger intellectual discourse an understanding of subordination that those privileged by white supremacy do not necessarily share. This knowledge is critical to the educational enterprise if the academy is to fulfill a moral commitment to anti-racism. ${ }^{114}$

1t continues to be my experience that middle-class students of color come to law school with a deep sense of responsibility for and commitment to the struggle against race and class subordination. The parents of many of my black students remember the "White" and "Colored" signs of the segregated south and the urban uprisings of the 1960s. Middle-class Latino students often have a parent or grandparent who was a migrant worker or a domestic. Increasingly our Asian-American students are the children of first-generation immigrants. The lessons of struggle in family histories are not lost on these students. There remains in their communities an ethic of remembering one's roots, of "representing the race" and of giving back. ${ }^{115}$ Family, community, and the students' own day-by-day experiences with racism shape these students' politics. Despite their mid-

112. See supra notes $24-25$ and accompanying text.

113. See Deborah C. Malamud, Affirmative Action, Diversity, and the Black Middle Class, 68 U. Colo. L. Rev. 939, 967-83 (1997); see also Fran Ainsley, Classifying Race, Racializing Class, 68 U. Colo. L. Rev. 1001, 1101 (1997) (arguing that affirmative action may be necessary to combat societal racism against black middle class).

114. 1 have elsewhere discussed the relationship between our universities and the larger project of anti-racism:

When racial diversity's purpose is anti-racism, or more inclusively, antisubordination, its defense is clear. . . . Certainly a university is justified, and I would argue morally and constitutionally obligated, to center its pedagogy and research around disestablishing white supremacist structures and ideologies. Once we acknowledge the continuing existence of racism and commit ourselves to its disestablishment, the applicant who has been identified and treated by society as a subordinated racial minority will bring to that freedom fighting enterprise a life experience that makes her peculiarly qualified for the task. Lawrence, Harvest, supra note 13, at 775 .

115. See W.E.B. DuBois, The Talented Tenth, originally published in The Negro Problem (1903), reprinted in Henry Louis Gates, Jr. \& Cornel West, The Future of the Race 133 (1996) (urging middle class blacks to take responsibility for social and economic uplift of poor blacks); see also Halimah D. Del.aine, A Critical Analysis of the Intersection of Race and Responsibility for the Black Middle Class (May 1, 2000) (unpublished paper, on file with the Columbia Law Review) (considering several black scholars' treatment of 
dle class status, they have an instinctive suspicion of privilege and an intuitive understanding of the many faces of subordination. ${ }^{116}$

The Michigan study's findings on the positive effect of diversity on students' ability to engage in more complex modes of thought offers additional evidence of the benefits of racial diversity even within an elitist model. Smart students get smarter when they are challenged to engage and understand novel or unfamiliar ideas and experiences. The task calls for both cognitive and emotional competence. It involves empathy as well as logic; a capacity for seeing the world through another's eyes and analyzing the more complicated picture that emerges when one examines a problem through multiple lenses. It is an enterprise that requires us to live and work with real people who talk back to us.

I have noted the strategic and substantive arguments for supporting the liberal defense of affirmative action, but the knot in my gut lingersan uneasiness that betrays my deep distrust of what is in the end a concession to conservatism. I worry that I may be attracted to the liberal defense because I share in the privilege it seeks to preserve. I am the ideal diversity candidate because I am different, but not too different from my white colleagues. I am among those black and brown folk who are best suited to the task of integrating the academy when the university's primary goal is the education and legitimization of an intellectual and professional elite. ${ }^{117}$

I am not at all certain that I am any closer to the resolution of my ambivalence. The dilemma I face is quite concrete. When a university's administration or legal counsel consults me concerning how best to frame or defend affirmative action policies; when one of the parties to a case asks me to serve as an expert witness in litigation or to write an amicus brief; when I speak to my colleagues at lunch or in faculty meetings, or address a student rally or demonstration; I must ask myself whether I can in good conscience recommend and support the liberal strategy.

black identity and responsibility and examining contemporary views of black middle class individuals in their twenties).

116. I am indebted to Roger Wilkins, the noted historian, journalist, and long time civil rights activist, for his insightful observation regarding the continuing need for affirmative action for middle-class hlacks. When Professor Wilkins was asked why the children of middle-class blacks like himself should benefit from affirmative action, he answered, "Because fighting racism in white institutions is hand to hand combat. If my daughter is among the best-trained and most committed freedom fighters, we must have her here with us. We need every warrior we can muster."

117. The ideal minority candidate for law school teaching positions is one whose resume is indistinguishable from her white male counterparts. See Charles R. Lawrence III, Minority Hiring in the A.A.L.S. Law Schools: The Need for Voluntary Quotas, 20 U.S.F. L. Rev. 429, 432-36 (1986) (describing the prerequisites to serious consideration for employment to tenure track positions at law schools). As Catherine MacKinnon has noted in the context of gender, the women most benefited by the liberal vision of equality are those "women who have been able to construct a biography that somewhat approximates the male norm." See Catherine A. MacKinnon, Difference and Dominance: On Sex Discrimination, in Feminism Unmodified: Discourses on Life and Law 32, 37 (1987). 
The diversity defense may prove most attractive to the center of a conservative Court, and therefore most likely to withstand legal attack, but should not I take a critical stance that challenges the strategy's inherent racism?

Ultimately, I believe I must do both. I must defend existing affirmative action programs because they have profoundly changed the face of America's institutions of higher learning. Without them, budding oases of diversity would once again turn arid, and they have pushed open doors for so many individuals who have done great good. I must, at the same time, challenge the gatekeepers of the still-too-narrow openings to push them open further.

Some may say, "He wants to have his radical principles and eat pragmatic politics too," and surely I do. I do not believe, however, that such an approach requires choosing between my principles and political pragmatism. I think it is about engaging in transformative politics. I use the words "transformative politics" to name the path by which we might rediscover and embrace the moral claim that first moved us to fight segregation and to challenge the structural and symbolic subordination of people of color.

The more radical moral claim for substantive equality and against subordination lives within the liberal defense of affirmative action, albeit in co-tenancy with a strong inclination toward the preservation of privilege. The claim for equality runs in the deepest currents of Bowen and Bok's River, and we can find a common ground there. I believe this common ground is discovered in the shared knowledge that our democracy was born in slavery, with slavery written into the very text of the Constitution, and in our understanding that the legacy of that horrible constitutional contradiction lives with us still. ${ }^{18}$ We have abolished slavery and outlawed discrimination in public accommodations, education, housing, and employment, but, as much as ever before, we live worlds apart, segregated by race and class. ${ }^{119}$ We send our children to schools that are increasingly separate and unequal. ${ }^{120}$

When Bowen, Bok, and other liberals argue that affirmative action is required for racial diversity, when they say diversity works, and when they cite evidence of friendship between black and white students and professional colleagues as proof thereof, they make a moral argument, an argument that is not just a matter of policy or practical consequence but of principle. Their argument supports affirmative action because it is just and because we are ethically bound to live out the ideals of our democ-

118. See Derrick Bell, And We Are Not Saved: The Elusive Quest for Racial Justice 34-35 (1987) (citing William Wiecek's list of eight different provisions in the Constitution that directly or indirectly accommodated slavery).

119. See generally Nancy Denton \& Douglas S. Massey, American Apartheid: Segregation and the Making of the Underclass 1-8 (1993) (arguing that racial inequality and urban poverty are largely results of racial residential segregation).

120. See id. at 153. 
racy and participate in the ongoing struggle to make democracy live. ${ }^{121}$ If the contradiction between the unifying American dream of inclusion and the reality of America's racism is, as Swedish sociologist Gunnar Myrdal observed, our American dilemma, ${ }^{122}$ then America's leading institutions of learning and research must make the resolution of that contradiction central to their mission.

The liberal argument for race-sensitive admissions is, in part, a utilitarian one. It is premised on a widely shared belief that the primary mission of colleges and universities is to educate those students who are likely to become the leaders of society in an increasingly diverse world. ${ }^{123}$ In Bowen and Bok's words, "The advantages of being able to understand how others think and function, to cope across racial divides, and to lead groups composed of diverse individuals are certain to increase."124 Education for leadership, however, is more than skills training for business executives, doctors, and lawyers. Our best colleges and universities have always played a central role in shaping our society's moral vision. We socialize our students. We teach them values by engaging them in moral discourse, but even more importantly, we teach by the example of our own leadership in the construction of our nation's conscience.

The argument for racial diversity cannot in the end rest only upon a university's choice to expose its students to a more colorful, more culturally diverse universe, or on a cost-benefit analysis of the need for an integrated elite in a soon-to-be majority non-white nation, or, as the Bakke Court argued, on the faculty's First Amendment right to academic freedom. We must integrate our universities because we cannot fulfill our democratic ideal until we have conquered the scourge of American apartheid. And we cannot teach and learn about racism in classrooms where only white folks are present. ${ }^{125}$

\section{The Politics Of Transformation}

If the common ground I share with my liberal colleagues is a moral commitment to ending racism, I must consider how best to use this understanding in the day-to-day work of fighting for more radical change while defending the gains made by affirmative action against attacks from the right. How, in other words, does one expose and tap the root of

121. See Charles R. Lawrence III, Promises to Keep: We are the Constitution's Framers, 30 How. L.J. 645, 653 (1987); Gerald Lopez, The Idea of a Constitution in the Chicano Tradition, $37 \mathrm{~J}$. Legal Educ. I62, I63-66 (1987). Each of these argue that constitutions are not static but dynamic reflections and products of a people's ongoing struggles for diguity, equality, and power.

I22. Gunnar Myrdal, An American Dilemma: The Negro Problem and Modern Democracy 1021 (1944).

123. Bowen \& Bok, supra note 25 , at 280.

I24. Id. at 279. This argument for diversity has special impact because, as Bowen and Bok's data show, the more selective the school a student attends, the more he or she is likely to accomplish and contribute in later life. Id. at $28 \mathrm{I}$.

I25. See Lawrence, Harvest, supra note I3, at 765 . 
liberals' ethical commitment to a more radical vision of equality while defending the good we have achieved through the diversity defense?

Transformative politics requires looking beyond winning or losing the particular legal dispute or political battle and asking how one's actions serve to reinforce people's awareness of our interdependence and mutual responsibility as members of the human family. Critical legal theorists have typically focused their attention on how best to expand the political consciousness of members of subordinated communities, urging progressive lawyers to use the legal system to increase people's "sense of personal and political power." 126 They have argued that the lawyer who adopts this "power-oriented" approach to justice advocacy "should always attempt to reshape the way legal conflicts are represented in the law, revealing the limiting character of legal ideology and bringing out the true socioeconomic and political foundations of legal disputes." 127 This admonition is directed primarily to the lawyer who is representing clients and political movements seeking to subvert the power of an oppressive state. ${ }^{128}$

Transformative politics also seeks to change the political consciousness of those privileged by systems of subordination. ${ }^{29}$ The task is to help the privileged comprehend the profound costs associated with inequality - the public costs of prisons, crime, illiteracy, disease, and the violence of an alienated underclass-as well as the personal costs of loneli-

126. Peter Gabel \& Paul Harris, Building Power and Breaking Images: Critical Legal Theory and the Practice of Law, 11 N.Y.U. Rev. L. \& Soc. Change 369, 376 (1983); see also Arthur Kinoy, Rights on Trial: The Odyssey of a People's Lawyer 57-59 (1983) (noting that success for an activist lawyer is not measured in "technical winning or losing" but in "the impact of the legal activities on the morale and understanding of the people involved in the struggle"). Paulo Freire argues that a true commitment to the people, and to the transformation of the reality by which they are oppressed, requires a theory of transforming action that assigns to the people a "fundamental role in the transformation process. . . . It is absolutely essential that the oppressed participate in the revolutionary process with an increasingly critical awareness of their role as Subjects of the transformation." Paulo Freire, Pedagogy of the Oppressed 120-21 (1971).

127. Gabel \& Harris, supra note 126, at 376.

128. For example, Gabel and Harris discuss how:

the defendants and their attorneys in the Chicago Eight conspiracy trial subverted the prosecution's attempt to use the sanctity of the legal process to recast the meaning of the anti-war protests at the 1968 Democratic convention, to recharacterize the protestors as hooligans, and to substitute a narrow and depoliticized legal description of the events. "By openly flaunting the hierarchical norms of the courtroom and ridiculing the judge, the prosecutor, and the nature of the charges themselves, they successfully rejected the very forms of authority upon which the legitimacy of the war itself depended.

Id. at 381 .

129. Freire argues that oppression "marks not only those whose humanity has been stolen, but also (though in a different way) those who have stolen it . . . [T] he great humanistic and historical task of the oppressed [is to] liberate themselves and their oppressors as well." Freire, supra note 126, at 28. 
ness and anomie in a world where no one is responsible for the pain of any other person. ${ }^{130}$

The work of subverting privilege may seem at odds with that which seeks to liberate the privileged. Sometimes it is, but 1 think that they are often complementary tasks. By this, 1 mean that when we reshape the presentation of legal conflicts to reveal the injury that inequality of power and privilege does to the subordinated, we may discover a concomitant injury to the privileged as well. Those with power, including the liberal defenders of affirmative action, may rely on the mystifying power of law to make their privilege seem legitimate to themselves as well as to subordinated others, and it surely unsettles them when subordinated people challenge the legitimacy of the very system that defines justice. But once the mask comes off, and liberals must resolve the conflict between justice and privilege, they may find that privilege in an unjust world has few comforts.

The particulars of this transformative practice are governed by context and do not lend themselves to bright line rules. The candid conversation with my Dean may sound quite different from the formal policy that is drafted at its conclusion. My comments at a faculty meeting may appeal to community, encouraging colleagues who share my privilege to see how much more we have to gain by doing the right thing. A brief filed in the Rios suit, on the other hand, will likely highlight the differences in the plaintiffs' and defendants' interests, identifying the real victims in the current system and encouraging the Court to act where the political process is unlikely to yield change. 1 will continue to call Boalt Hall and UCLA and Texas "segregated law schools" so long as they lack significant numbers of African Americans and Latinos. Civil rights organizations might hold hearings at Berkeley and UCLA and take testimony on the causes and effects of the re-segregation of the university. Such hearings would document systemic conditions of inequality throughout the California educational system as well as the University's participation in the perpetuation of those conditions. Since 1989, Professor Michael Olivas, chair of the professors committee of the Hispanic Bar Association of Maricopa County, has compiled the "Dirty Dozen" list. The "Dirty Dozen" list points a "finger of shame" at those law schools located in areas with large number of Latinos, where Latino faculty members are underrepresented. ${ }^{131}$ A clear oppositional voice must counter the story that says these law schools are not the perpetrators and that therefore neither

130. For a utopian argument for affirmative action, see Lawrence \& Matsuda, supra note 10, at 270-80; see also Mari Matsuda, On Causation, 100 Colum. L. Rev. 2195, 2217 (2000) (offering a utopian vision of causation doctrine to address moral responsibility for harms done to others).

131. Since its inception, the "Dirty Dozen" lists have included some of the nation's leading law schools such as Yale, Harvard, and New York University. According to Professor Olivas, the notoriety of the list stimulates demand and has resulted in the hiring of forty Hispanic faculty in those institutions making the list in previous years. Ronald Sal Panuco, Top Law Schools Still Rank Among Latino Dirty Dozen, Los Abogados (Hispanic Bar 
injury nor crime exists. ${ }^{132}$ In each of these settings, I must determine how to subvert the legitimacy of the part of the liberal defense that serves oppression and support the liberating spirit at its core.

The University of Michigan cases provide an instructive example of the need for transformative politics. Concerned that the University would not adequately represent the interests of minority and white applicants and of other students who desire the benefits of attending a raciallydiverse university, black, Latino, Filipino-American, Asian-American, and white students, and several pro-affirmative action coalitions have intervened in both the Grutter and the Gratz litigation. ${ }^{133}$ The intervenors have taken a first important step in demanding that the true victims' voices be heard and in subverting the legal fiction that only recognizes injury to the white plaintiffs and makes the University a defender, never a violator, of minority rights. The task for the Michigan intervenors cannot be subversion alone. They will gain little by simply telling the Court that both the plaintiffs and defendants are up to no good.

Instead, they must do two things at once. They must unmask the "big lie" that provides the starting point for the University's "liberal" defense, proffering evidence of the University's past and continuing discriminatory practices and explaining to the court why a race-conscious admissions policy is a necessary antidote to the conscious racism of the past as well as the unconscious and institutional racism of the present. ${ }^{134}$

Association of Maricopa County) Jan. 1999, at http://www.losabogados.org/newsletters/ jannews.html (last visited Apr. 12, 2001) (on file with the Columbia Law Review).

132. See supra notes 75-77 and accompanying text (discussing the difference between the victim and perpetrator perspectives of equality).

133. Grutter v. Bollinger, 188 F.3d 394 (6th Cir. 1999); Gratz v. Bollinger, 122 F. Supp. 2d 811 (E.D. Mich. 2000).

134. The early stages of this litigation have demonstrated the efficacy of this approach. On December 13, 2000, the United States District Court for the Eastern District of Michigan granted defendants' motion for summary judgment in Gratz with respect to the admissions policy of the College of Literature, Science and the Arts (LSA) of the University of Michigan, holding that "the LSA's current admissions program meets the requirements . . . set forth by Justice Powell in Bakke and is therefore constitutional." While the District Court's decision turned on its adherence to Bakke's "diversity defense," the court noted in its opinion that two interests had been asserted in support of the LSA's race-conscious admissions policies: "The University Defendants assert that the LSA has a compelling interest in the educational benefits that result from having a diverse student body, whereas the Defendant-Intervenors assert that the LSA has a compelling interest in remedying past and current discrimination against minorities." 122 F. Supp. 2d at 816 . In a footnote the Court explained that "only the Defendant Intervenors have asserted that the LSA's admissions policies serve a remedial purpose. The University Defendants have never justified the LSA's race-conscious admissions on remedial grounds." 1d. at 816 n.5. Intervenors supplemented the University's case with evidence that the University was reluctant to offer, despite the fact that such evidence was potentially helpful to its case. For example, the Defendant Intervenors brief in support of Defendants motion for summary judgment includes offers of undisputed fact on the following issues: the de facto segregation of the University prior to affirmative action; the systematic bias, discriminatory impact and minimal predictive validity of standardized tests employed in admissions; that a critical mass of minority students is required to dismantle persistent racial stigma and 
At the same time, they must help the University, and even the Court, to understand how the compelling interest in diversity is inseparable from the compelling interest in the remedy of the university's and society's racism. The task here is to find a way to make the doctrinal argument from Bakke-that the University must have the freedom to create a racially diverse learning environment-without allowing the University to escape its legal and moral responsibility for curing itself and society of the disease of racism.

The measure of success in this effort will not turn on whether Gratz $v$. Bollinger is won or lost, but will depend on what is learned in the process. During the course of this litigation, will we discover, document, and better understand the myriad ways that the university's past and present practices contribute to and reinforce societal racism? Will the faculties and administrations at elite colleges and universities develop new and creative affirmative action strategies that can withstand the scrutiny of a conservative Court while increasing the number of students who come to their schools from diverse race and class backgrounds? Will progressive advocates for more radical versions of inclusion be inspired to engage in the political battle to transform the hearts and minds of their brothers and sisters? If the Court upholds Michigan's admissions policy by legitimizing a system that recreates an educational elite, and if the University does not realize its responsibility for leadership in the quest for equality, there will be little reason to rejoice. If the University is truly committed to integration and racial equality, a Supreme Court decision striking down Michigan's current admissions program need not mean the end of affirmative action. If we have the political will to do justice, it can be accomplished.

\section{JOINING THE RIVER}

What of Proposition 209? Berkeley's chancellor has argued that the University of California cannot engage in affirmative action because it is "constrained by a statewide ban on preferences." 135 Short of civil disobedience, what course can the University take to live out its moral obligation? I want to suggest that the legal constraints imposed by Proposition 209, the Hopwood decision, and other provisions prohibiting the use of race in university admissions may offer an opportunity to move closer to

stereotypes by white students and faculty, to ensure full participation by minority students in a campus climate still marked by racism, and to achieve the full educational benefits of integration and diversity. Defendant-lntervenor's Response in Opposition to Plaintiffs' Renewed Motion for Summary Judgment at 13-17, 19-24, 31, Gratz v. Bollinger, $122 \mathrm{~F}$. Supp. 2d 811 (E.D. Mich. 2000) (No 97-CV-75231-DT). But see Grutter v. Bollinger, No. 97-CV-75928-DT, 2001 U.S. Dist. LEXIS 3256 at *140-*42 (E.D. Mich. Mar. 27, 2001) (finding that testimony presented by intervenors of past and contemporary discrimination was evidence of societal discrimination, rather than evidence of discrimination against those applicants who benefited from the law school's admissions policy, and holding that race-conscious decision-making cannot constitutionally remedy societal discrimination).

135. See supra note 70 and accompanying text. 
the radical vision of affirmative action, a vision that adopts the victim perspective and creatively shapes remedies that directly address remaining conditions of inequality. ${ }^{136}$

Texas's "ten percent plan" provides one model. It requires the University of Texas to admit the top ten percent of every high school's graduating class. The criterion for admission is race neutral, but it has brought more African-American and Mexican-American students to the Austin campus than had the outlawed affirmative action program. By treating the top students at each of the state's schools as "most qualified," the University takes responsibility for existing discriminatory conditions in a state where most schools are still racially segregated and unequally financed, training future leaders from oppressed and under-served communities, and challenging the state to make its separate and unequal schools equal. ${ }^{137}$ In California it appears that a similar plan proposed by Governor Gray Davis will have little impact on the racial integration of the UC system, much less the Berkeley campus, ${ }^{138}$ but this may only mean

136. See Hopwood v. Texas, 78 F.3d 932, 946 (5th Cir. 1996) (rejecting Justice Powell's diversity argument and asserting that the use of race to achieve diversity of points of view in educational settings assumes "that race controls [one's] point of view"); see also Darlene C. Goring, Private Problem, Public Solution: Affirmative Action in the 21st Century, 33 Akron L. Rev. 209, 274-87 (2000) (arguing that a new weapon in the fight to eradicate racism ought to be introduced in light of the restrictions reflected in Hopwood and other decisions: a Congressional inquiry into the operation of present and past discrimination at educational institutions, which could then be used to implement and uphold race-based remedial programs); Lawrence, Harvest, supra note 13, at 770-74 (arguing that the Hopwood decision is an extension of Justice Powell's troublesome restriction on remedial affirmative action in Bakke, which has the effect of undermining what ought to be affirmative action's true purpose of fighting racism); Barbara Phillips Sullivan, The Gift of Hopwood: Diversity and the Fife and Drum March Back to the Nineteenth Century, 34 Ga. L. Rev. 291, 296 (1999) (arguing that Hopwood was right to reject the diversity rationale because the diversity rationale puts "self-defined interests" of educational institutions above the need for racial justice and equality).

137. The "ten-percent plan" was enacted by the Texas state legislature in March 1997. The plan entitles the top ten percent of the graduating class of each accredited high school in Texas to attend the University of Texas (UT) at Austin or any other UT or A\&M cainpus. The plan arose as a means of increasing minority enrollment in Texas's state universities in response to the 1996 decision in Hopwood. See William E. Forbath \& Gerald Torres, Symposium, Merit and Diversity After Hopwood, 10 Stan. L. \& Pol'y Rev. 185, 185 (1999). Forbath and Torres argue that the plan presents the possibility for dismantling the traditional elitism of top state research universities like UT Austin and bringing about "a significant increase in diversity across racial, ethnic, and economic lines." Id. at 186-87. In addition, the plan has heightened attention to the radical inequities in public education by raising the question, "How is it that some public schools in Texas cannot prepare their students either for university level work or the economy?" Id. at 189.

138. On March 19, 1999, the University of California Board of Regents adopted the policy to guarantee admission to all California applicants who ranked in the top four percent of their high school class. The plan, to take effect in the fall of 2001, was championed by Governor Davis as a mean of boosting minority numbers in the UC system. Kenneth R. Weiss, UC Regents OK Plan to Admit Top 4\%, L.A. Times, Mar. 20, 1999, at A18. However, it appears that the plan will do little to boost minority numbers, with only an estimated 877 more blacks and Hispanics qualifying for the University of California 
that states such as California and Michigan need to identify their own peculiar discriminatory conditions and find the admissions policies that address them.

The Rios litigation suggests several possibilities that would identify talented students that are representative of diverse communities. For instance, a school could give less weight to discriminatory SATs and LSATs, or establish a floor above which students would be considered on other criteria. ${ }^{139}$ If fifty percent of Berkeley students come from five percent of California schools, why not give extra points to students from schools whose graduates seldom get into Berkeley, ${ }^{140}$ or target zip codes or census tracts with conditions that indicate that young people from those areas have overcome significant obstacles of race and class discrimination? ${ }^{141}$ California prisons hold disproportionate numbers of African

under the new plan. Ben Wildavsky, Whatever Happened to Minority Students? Universities Try Risky New Steps to Diversify, U.S. News \& World Rep., Mar. 22, 1999, at 28, 29. A University of California faculty group concluded in a study that "only 5 percent of the newly eligible students seeking entry under the ... new plan would be AfricanAmerican and 20 percent would be Latino." V. Dion Haynes, U. of California Alters Its Policy on Admissions; Change Aims to Increase Number of Minority Students, Chi. Trib., Mar. 20, 1999, at 1. Whites and Asian Americans would comprise $56 \%$ and $11 \%$ respectively. $1 \mathrm{~d}$.

139. In the wake of Hopwood and Proposition 209, the University of Texas and the University of California devised new admissions plans that aimed to reduce the significance of the numerical grid consisting of GPAs and SAT scores in making admissions decisions. James Traub, The Class of Prop. 209, N.Y. Times, May 2, 1999, §6 (Magazine), at 44, 50-51, 76. The University of Texas asked applicants to describe their achievements in light of disadvantages they may have experienced. Id. at 78. Similarly, the University of California considered SAT scores in the context of the applicant's "history and circumstances," including attendance at a substandard school. Id. Claude Steele and Joshua Aronson suggest that efforts to reduce the influence of SAT scores are logical in light of studies showing that minority test performance is affected by fear of racial stereotyping because these students are aware that their test results will be used to judge intellectual ability. See Claude M. Steele \& Joshua Aronson, Stereotype Threat and the Intellectual Test Performance of African Americans, $69 \mathrm{~J}$. Personality \& Soc. Psychol. 797, 808 (1995).

140. Some private philanthropists have identified communities in which children may be less inclined or less financially able to attend college and have created programs to enable them to attain levels of higher education, including promising elementary and junior high school children scholarships if they succeed through high school. For example, the nationwide "I Have a Dream" program links fifth-grade children with local mentors, who work with the children until high school graduation, and guarantees these children college scholarships. See Sheba R. Wheeler, At-Risk Students Given Tools to Dream, Denv. Post, June 11, 1998, at B-02. Similar programs have arisen throughout the country. See, e.g., Robert Dorr, Scotts Giving Scholarships to Youths Facing Challenges, Omaha World-Herald, Oct. 21, 1999, at 1 (describing private program funding scholarships for Omaha-area colleges for graduates of a local elementary school "who have kept up their grades and graduated from high school"); Melanie Markley, A Dream Realized, Hous. Chron., Mar. 20, 2000, at A24 (describing Merrill Lynch college scholarship fund set up for first-graders at Houston elementary school).

141. Richard Fallon has described one proposal by the UCLA School of Law Admissions Task Force which, in 1996, recommended basing decisions partly on a "socioeconomic index." This would include, among a number of other factors, whether 
Americans and Latinos. Universities could advantage students from neighborhoods with high rates of incarceration. Why not give extra points to the student who has had the experience of being racially isolated in his or her school? This would include black kids who have negotiated and survived in privileged white schools and white kids who have stuck it out in predominantly black or Latino schools. ${ }^{142}$ Race-neutral criteria can identify young people who would bring to Berkeley the special skills and experience that relate directly to the University's mission of fighting racism.

1n the aftermath of Proposition 209, Berkeley adopted new admissions criteria not unlike some of those I have suggested. The University evaluates applicants on a range of academic and non-academic achievements, and those achievements are considered "in the context of the opportunities an applicant has had, any hardships or unusual circumstances the applicant has faced and the ways in which he or she has responded to them." 143 Admissions files include a detailed profile of the applicant's high school so that the reader can recognize the student who has succeeded despite attending a substandard school and consider the applicant's SAT score in light of his or her unique history or circumstance. ${ }^{144}$

[tlhe poverty rate in the zip code in which the student attended high school is greater than $18 \% ; \ldots[\mathrm{m}]$ ore than $5 \%$ of the adults in the zip code where the student resided during high school receive welfare; . . . [or] [m] ore than $20 \%$ of the households where the student resided during high school are female-headed.

Richard H. Fallon, Jr., Affirmative Action Based on Economic Disadvantage, 43 UCLA L. Rev. 1913, 1927 n.47 (1996) (quoting UCLA Admissions Task Force, Final Report on Law School Admissions, Apr. 11, 1996).

142. This criterion would have several salutary effects in addition to its race neutrality. 1t would include middle-class black and Latino students who would not be identified by criteria based on socio-economic disadvantage. Most impoverished black and Latino students have suffered extreme deprivation of educational opportunity and are not even in the running for slots in elite universities. Thus, criteria based on socio-economic disadvantage are not effective in increasing rates of minority enrolment of those schools. Criteria based on racial isolation, however, might be. Black and Latino students who attend predominantly white schools will have the experience of surviving in a predominantly white environment, of representing the race, and of cross-cultural teaching and learning. The criterion will also include the racially isolated white student in a predominantly black or Latino school. Like the black student in a predominantly white school, this student will have expertise in cross-cultural discourse and in teaching and learning about racism. The criterion might also provide an incentive for parents to choose schools where their children are not in the majority and thus further the goal of school integration.

143. Traub, supra note 139 , at 78 .

144. Richard C. Atkinson, president of the University of California, has proposed that the University of California end the use of SATs as a requirement for admission. Atkinson criticized the use of SAT scores to rank students for admission, saying they are "not compatible with the American view on how merit should be defined and opportunities distributed." Diana Jean Schemo, Head of U. of California Seeks to End SAT Use in Admissions, N.Y. Times, Feb. 17, 2001, at A1. The president's proposal "came several years after a university faculty committee urged that the SAT be made optional to increase the number of black and [Latino] students gaining admission." Id. 
Not surprisingly, opponents of affirmative action have attacked these efforts to look beyond test scores and give more attention to each individual's unique qualifications as transparent attempts to reinstitute "unlawful" racial criteria. ${ }^{145}$ The view of many of affirmative action's liberal supporters that the primary benefit of these new, more individualized criteria is their opacity is also troubling. Thus, defenders of affirmative action, not unlike detractors, see the new criteria as a pretense for racial preference, albeit a pretense that is justified. ${ }^{146}$ Their defense does not rest on a belief that the criteria reflect skills, perspectives and knowledge valuable in a university setting. That liberals as well as conservatives have viewed these new standards for admission as little more than old style "racial preference" in disguise reveals how difficult it is for liberals to eschew conventional definitions of merit. This very failure to abandon old ways, in substance and spirit, as well as form, has made the liberal defense susceptible to attack.

A better and more defensible approach would re-imagine merit in light of the university's commitment to the goal of fighting racism. When that goal is articulated, admissions criteria aimed at identifying those best qualified to achieve it are transparent in the best sense of that word. They clearly reveal and make apparent a legitimate means of achieving an important purpose.

But won't many students who come from poor schools be poorly prepared for the rigorous academic requirements at our top schools? Certainly, some of them will be, but this problem has solutions. We know how to run programs that teach intelligent, motivated students the skills needed to survive and even excel at elite universities. ${ }^{147}$ Such programs

145. Stephan Thernstrom claims that admissions departments have "figured out how to circumvent the law." Traub, supra note 139, at 78 .

146. James Traub, in an article that describes the new Berkeley admissions process in quite sympathetic terms, asks, "How should we feel about the murky, opaque fiddling that is bound to fill the vacuum created by the abolition of preferences?" $1 \mathrm{~d}$. at 78 . His tentative answer: "[P]erhaps we should accept a dent in meritocratic purity as a fair price for admitting students as individuals, not group members." Id. Traub quotes Jack Critin, a conservative professor of political science who quit the admissions committee when the new criteria were promulgated. "' 1 don't think we're in the therapy business,' Critin says. 'I think what we have happening here is an attack on the idea of merit as conventionally defined.'" Id.

147. We have been successful in developing undergraduate academic support programs in universities nationwide. For a survey of some of these successes, see John $\mathbf{E}$. Roueche et al., College Responses to Low-Achieving Students: A National Study 86-89 (I984). Law schools have developed a range of academic support programs as well, including the Council for Legal Education Opportunity (CLEO) pre-start summer institutes, as well as classes, study groups, and workshops offered during the school year. Kathy L. Cerminara, Remembering Arthur: Some Suggestions for Law School Academic Support Programs, 2 I T. Marshall L. Rev. 249, 255 (1996). Started in 1968, CLEO provides pre-law school summer programs and served both to recruit students wbo might not otherwise be qualified based on LSAT scores and GPA and to develop the academic skills of students who had already been admitted to law school. Id. at 262-63. 
require only the commitment and resources to teach them, and a belief that students who do not come from privilege can learn.

Furthermore, the university can actively participate in righting an unequal elementary and secondary education system. Why not establish partnerships between the university and schools in poor minority neighborhoods? ${ }^{148}$ Why not send university students out to teach reading, math, calculus, chemistry, and literature to students in those schools? Why not do as some philanthropists have done, and tell these students while they are still in elementary school, "If you are an A student in this school you will go to Berkeley on a full scholarship"? 149

When confronted with the stark inequalities of our nation's elementary and secondary education systems, opponents of affirmative action often assert their sense of outrage at the system's inadequacies, but quickly argue that institutions of higher learning are neither responsible for nor capable of correcting those inequalities. ${ }^{150}$ This argument exempts elite universities, more than others, from any obligation to right the fundamental injustices of our educational system. 1t holds that great universities like those at Berkeley, Austin, or Ann Arbor should focus on path-breaking research and scholarship and the education of the best and the brightest. If an uneven playing field exists, lesser universities

148. The University of California spent $\$ 137$ million in 1999 on partnerships with public schools and other outreach efforts to recruit more minority students from local high schools. See Wildavsky, supra note 138 , at $28-29$; see also Renee C. Lee, New Diversity Paths Get Urgent Attention, Fort Worth Star-Telegram, Jan. 24, 1999, at 1 (deeming partnership between University of Houston and local high school responsible for lower high school drop-out and higher college matriculation numbers). The University of Texas at Austin has undertaken similar efforts to recruit students from schools underrepresented at the university through its Longhorn Opportunity Scholarships. Each year, the program offers full scholarships to attend University of Texas at Austin to a certain number of students at selected high schools. The program also includes academic support for scholarship recipients. See Office of Student Fin. Servs., Univ. Tex. at Austin, Longhorn Opportunity Scholarship, at http://www.utexas.edu/ student/finaid/quickinfo/los.html (last visited Apr. 12, 2001) (on file with the Columbia Law Review).

149. See Lee, supra note 148, at 1 (noting that the University of Texas at Arlington targets local eighth graders and promises admission to the university if they fulfill certain academic requirements). Similarly, legislation following the Hopwood decision requires the University of Texas to accept "anyone who graduates in the top 10 percent of any state high school." See supra note 137 and accompanying text.

150. See, e.g., Thernstrom \& Thernstrom, supra note 32, at 396 (suggesting that compensatory education is a difficult task for institutions of higher learning as professors are not skilled in providing remedial education); see also Dinesh D'Souza, llliberal Education 232-33, 252-53 (1991) (arguing that the "special stigma" of racial preferences and relative unpreparedness of minority students should convince universities to admit applicants based only on their "measured capabilities"); Stephen Kershnar, Strong Affirmative Action Programs at State Educational Institutions Cannot Be Justified via Compensatory Justice, 11 Pub. Aff. Q. 345, 360 (1997) (“Merely having benefitted from unjust injuring act[s] or being a member of a community that owes a debt of compensation to racial minorities and women, are not sufficient grounds to override the duty owed to the white male."). 
should make it level. Until then, the best universities should educate those who are best prepared. ${ }^{151}$ "The University of California in its eight institutions can not reform the public schools," says Berkeley's Chancellor Robert Berdahl, when asked about the University's role in expanding the pool of eligible minority students. ${ }^{152}$ Yet to describe the goal of academic excellence as incompatible with that of societal reform creates a false dichotomy. Nor does it accurately describe what great universities have done in practice.

Great universities have always combined teaching and research with leadership in solving society's most pressing problems. Whether in the discovery of a vaccine, the creation of new technology, the formulation of foreign trade agreements, or the development of models for domestic economic and social policy, the academy has often done its most significant intellectual work through direct hands-on involvement with the development and implementation of public policy. "The best" are exactly who should address our most pressing societal needs.

When people say, "But we cannot lower standards," I hear a fear that taking on talented disadvantaged students will diminish the stature and status of a great school. This is a lie, ripe with racist presupposition. Affirmative action has made Berkeley, Texas, and Michigan better places, and, if the attack on affirmative action forces us to create strategies of empowerment that reflect deeper and more radical versions of affirmative action, the best of our schools will become greater still.

The river in the title of Bowen and Bok's book, The Shape of the River, is a metaphor borrowed from Mark Twain's Life on the Mississippi. "Twain created an image of the river as both physically central to the United States and symbolically central to the progress of the country." 153 Bowen and Bok say that their river represents "the flow of talent-particularly of talented black men and women-through the country's system of higher education and on into the marketplace and the larger society." 154 They compare nurturing this flow of black talent "to moving down a winding river, with rock-strewn rapids and slow channels, muddy at times and clear at others. Particularly when race is involved, there is nothing simple, smooth, or highly predictable about the education of young people." 155

The former presidents of Harvard and Princeton cast themselves as the river boat pilots in this metaphor, navigating the river from "point to point." They say the pilots must know "every depth, every deceptive

151. The University of California at Riverside, a UC campus that is significantly less prestigious and selective than Berkeley or UCLA, has implemented an outreach program into area high schools, junior high schools, and elementary schools to attempt to foster academic achievement. Traub, supra note 139, at 46, 49 .

152. Id. at 49 .

153. Bowen \& Bok, supra note 25 , at xxi.

154. Id.

155. Id. 
shoal, and every hidden snag of the river. ... [They must] know the river's features in every imaginable condition, and from either direction." 156

I am struck by who is the river in this metaphor-"dark," "muddy," "deceptive," "unpredictable"-and who are the pilots, who must know this river so that it can be navigated, if not controlled. I am also reminded of another river metaphor. 1t is the metaphor of historian Vincent Harding's book, There Is a River: The Struggle for Black Freedom in America. ${ }^{157}$ Here too, we African Americans are the river. But Harding's river is the river of liberation-the many currents of black survival, protest, radical resistance, and rebellion. It is the river of the Negro spirituals and the rivers of Langston Hughes's magnificent poem. ${ }^{158}$ For Harding, this historical river of struggle for Black freedom is "at its heart a profoundly human quest for transformation, a constantly evolving movement ... toward new social structures filled with justice, equity, and compassion. ... [A]t its deepest levels the river moves toward a freedom that liberates the whole person and humanizes the entire society." 159

This is a very different view of the river than the one from the riverboat pilot's seat. Ultimately this river cannot be tamed, controlled, or even navigated. Better to join it. Better to become part of its powerful, joyful current of transformation.

156. $1 d$.

157. Vincent Harding, There Is a River: The Black Struggle for Freedom in America (1981).

158. Langston Hughes, The Negro Speaks of Rivers, in The Poetry of Black America 72, 72 (Arnold Adoff ed., 1973).

159. Harding, supra note 157 , at xxiv. 